2014

\title{
Documentation of Caddo Vessels in the Robert L. Turner Collection at Stephen F. Austin State University
}

Timothy K. Perttula

Heritage Research Center, Stephen F. Austin State University

Robert Z. Selden Jr.

Heritage Research Center, Stephen F. Austin State University

Mark Walters

Follow this and additional works at: https://scholarworks.sfasu.edu/ita

Part of the American Material Culture Commons, Archaeological Anthropology Commons, Environmental Studies Commons, Other American Studies Commons, Other Arts and Humanities Commons, Other History of Art, Architecture, and Archaeology Commons, and the United States History Commons

Tell us how this article helped you.

This Article is brought to you for free and open access by the Center for Regional Heritage Research at SFA ScholarWorks. It has been accepted for inclusion in Index of Texas Archaeology: Open Access Gray Literature from the Lone Star State by an authorized editor of SFA ScholarWorks. For more information, please contact cdsscholarworks@sfasu.edu. 
Documentation of Caddo Vessels in the Robert L. Turner Collection at Stephen F. Austin State University

\section{Creative Commons License}

\section{(c) (1) \&}

This work is licensed under a Creative Commons Attribution-NonCommercial 4.0 International License 


\section{Documentation of Caddo Vessels in the Robert L. Turner Collection at Stephen F. Austin State University}

Timothy K. Perttula, Robert Z. Selden Jr., and Mark Walters

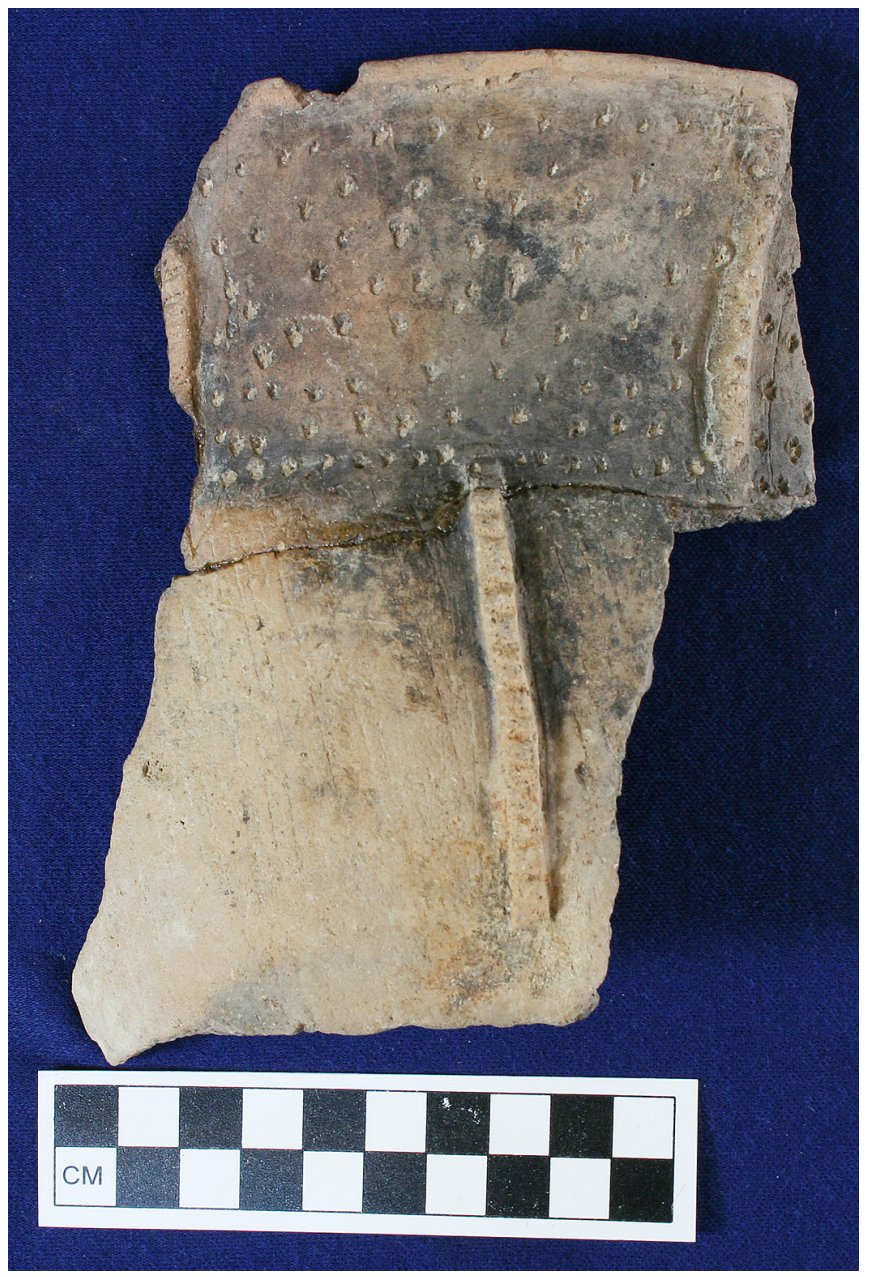

Special Publication No. 36

Friends of Northeast Texas Archaeology 
Distribution, Bo Nelson, 344 CR 4154

Pittsburg, Texas 75686

RBoNelson@aol.com

Cover art:
Utility ware jar rim sherd from the Rumsey site (41CP3)

Copyright (C) 2014, Friends of Northeast Texas Archaeology (Austin and Pittsburg) 


\section{Table of Contents}

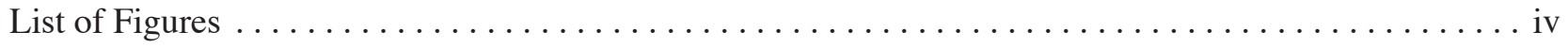

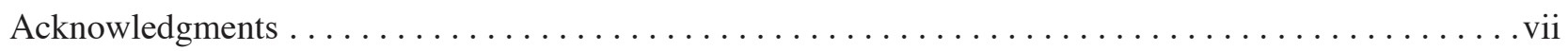

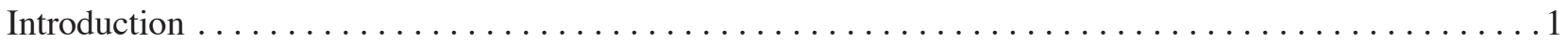

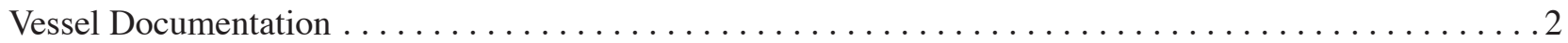

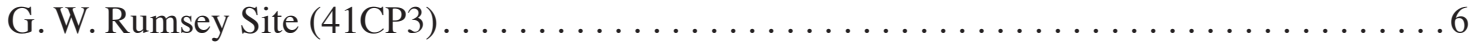

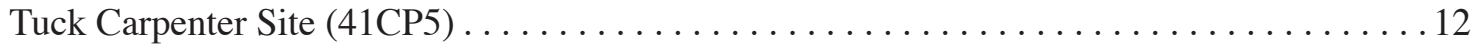

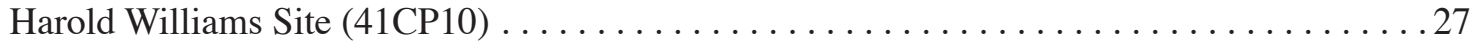

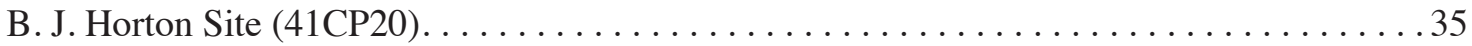

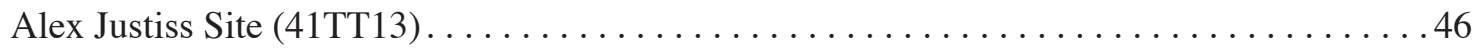

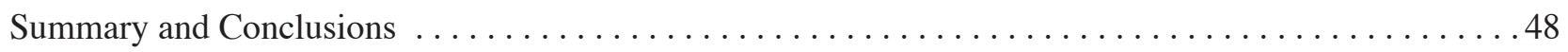

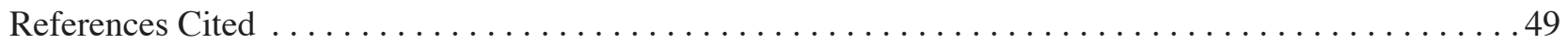




\section{List of Figures}

1. Location of the G. W. Rumsey (41CP3), Tuck Carpenter (41CP5), Harold Williams (41CP10), B. J. Horton (41CP20), and Alex Justiss (41TT13) sites in the Big Cypress Creek basin

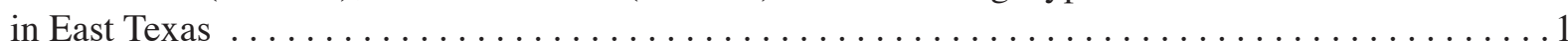

2. Varieties of Ripley Engraved carinated bowls and compound bowls: a, var. McKinney; b, var. Gandy; c, var. Galt; d, var. Caldwell; e, var. Cash; f, var. Carpenter; g, var. Pilgrims;

$\mathrm{h}$, var. Williams; i, k, var. unspecified; $\mathrm{j}$, var. Reed ...................... 4

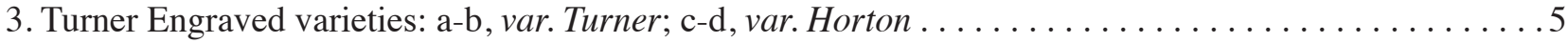

4. Ripley Engraved, var. McKinney carinated bowl from the G. W. Rumsey site . . . . . . . . . 6

5. Ripley Engraved, var. Galt compound bowl from the G. W. Rumsey site $\ldots \ldots \ldots \ldots \ldots \ldots \ldots$

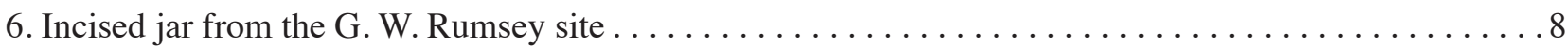

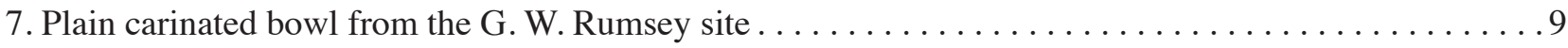

8. Appliqued-punctated jar from the G. W. Rumsey site $\ldots \ldots \ldots \ldots \ldots \ldots \ldots \ldots \ldots \ldots \ldots \ldots \ldots \ldots \ldots \ldots \ldots \ldots$

9. Ripley Engraved, var. Galt carinated bowl from the G. W. Rumsey site $\ldots \ldots \ldots \ldots \ldots \ldots \ldots \ldots$

10. Maydelle Incised jar from Burial 2 (Pot 9) at the Tuck Carpenter site . . . . . . . . . . . . 13

11. Probable Pease Brushed-Incised jar from Burial 9 (Pot 1) at the Tuck Carpenter site ...........14

12. Ripley Engraved, var. Carpenter carinated bowl from Burial 13 (Pot 1)

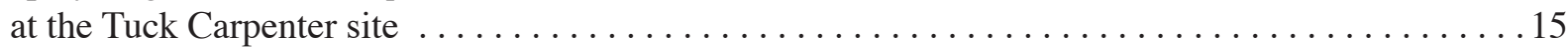

13. Ripley Engraved, var. Carpenter carinated bowl from Burial 18 (Pot 2)

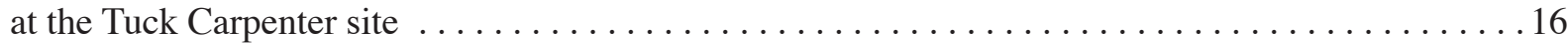

14. Ripley Engraved, var. unspecified carinated bowl from Burial 19 (Pot 12)

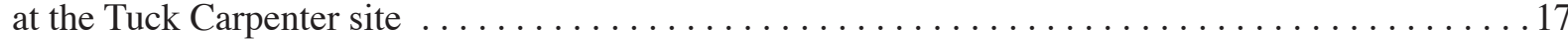

15. Ripley Engraved, var. Galt carinated bowl from Burial 24 (Pot 3) at the Tuck Carpenter site........ 18

16. Ripley Engraved, var. Galt carinated bowl from Burial 25 (Pot 2) at the Tuck Carpenter site........ 19

17. Incised bowl from Burial 25 (Pot 9) at the Tuck Carpenter site . . . . . . . . . . . . . . . . 20

18. Engraved motif on Ripley Engraved, var. Galt bowl from Burial 26 (Pot 1)

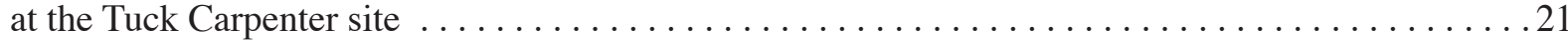

19. Maydelle Incised jar from Burial 30 (Pot 5) at the Tuck Carpenter site $\ldots \ldots \ldots \ldots \ldots \ldots \ldots \ldots \ldots$

20. La Rue Neck Banded jar from Burial 33 (Pot 6) at the Tuck Carpenter site .................23

21. Plain bottle from Burial 39 (Pot 5) at the Tuck Carpenter site . . . . . . . . . . . . . . . 24

22. Mockingbird Punctated jar from the Tuck Carpenter site . . . . . . . . . . . . . . . . . . . 25

23. Ripley Engraved, var. Galt carinated bowl from the Tuck Carpenter site $\ldots \ldots \ldots \ldots \ldots \ldots \ldots$

24. Turner Engraved, var. Turner compound bowl from Burial J (Pot 3) at the Harold Williams site ... . 28

25. Ripley Engraved, var. Gandy compound bowl from Burial J (Pot 5) at the Harold Williams site . . . . 29 
26. Maydelle Incised jar from Burial K (Pot 1$)$ at the Harold Williams site $\ldots \ldots \ldots \ldots \ldots \ldots \ldots \ldots$

27. Ripley Engraved, var. unspecified carinated bowl from Burial K (Pot 8) at the Harold Williams site ...31

28. Ripley Engraved, var. McKinney carinated bowl from Burial N (Pot 1) at the Harold Williams site... 32

29. Turner Engraved, var. Turner compound bowl from Burial N (Pot 4) at the Harold Williams site ....33

30. Ripley Engraved, var. Cash compound bowl from Burial N (Pot 5) at the Harold Williams site.......34

31. Ripley Engraved, var. Carpenter carinated bowl from Burial 2 (Pot 2) at the B. J. Horton site.......36

32. Probable Pease Brushed-Incised jar from Burial 2 (Pot 8) at the B. J. Horton site . . . . . . . . . . . 37

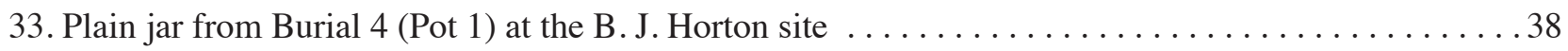

34. Ripley Engraved, var. unspecified compound bowl from Burial 4 (Pot 2) at the Harold Williams site. . . . . . . . . . . . . . . . . . . . . . . . . . . 39

35. Sections of Pots 7,10A, and 10B from Burial 4 at the Harold Williams site;

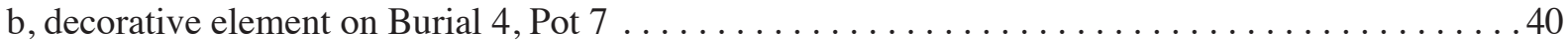

36. Decorative elements on Burial 4, Pot 10A at the Harold Williams site . . . . . . . . . . . . 41

37. Decorative elements on Burial 4, Pot 10B at the Harold Williams site . . . . . . . . . . 42

38. Ripley Engraved, var. Williams-Carpenter carinated bowl from Burial 10 (Pot 8) at the Harold Williams site: a, vessel section; b, decorative elements. . . . . . . . . . . . 43

39. Decorative elements on unidentified engraved compound bowl from Burial 10 (Pot 12) at the Harold Williams site . . . . . . . . . . . . . . . . . . . . . . 44

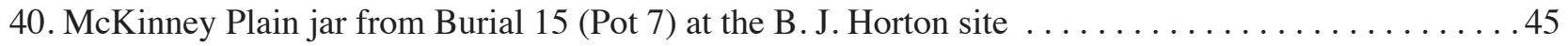

41. cf. Ripley Engraved, var. Gandy carinated bowl from Burial 24 (Pot 1) at the Alex Justiss site ..... .47 


\section{Acknowledgments}

We would like to thank Dr. George Avery of the Anthropology and Archaeology Laboratory for permission to document these vessels from the Robert L. Turner collection at Stephen F. Austin State University, and for providing the work space necessary to complete the documentation. Dr. Avery also provided the photographic images used in this report. The other figures were prepared by Lance Trask. 


\section{Introduction}

Perttula et al. (2010) documented more than 300 ceramic vessels in the Robert L. Turner, Jr. collection from ancestral Caddo burial sites in East Texas, primarily from the Big Cypress Creek basin, but also including vessels from sites in the middle Sabine, lower Sulphur River, and Neches/Angelina River basins. When the Turner collection was donated to Stephen F. Austin State University (SFASU) in 2012, it was noted that some of the vessels in the collection had not been documented by Perttula et al. (2010). In the spring of 2014 we had an opportunity to remedy the situation, and with the permission of DR. George Avery of the Anthropology and Archaeology Laboratory at SFASU, we have documented an additional 38 vessels in the Turner collection. These vessels are from the G. W. Rumsey (41CP3), Tuck Carpenter (41CP5), Harold Williams (41CP10), B. J. Horton (41CP20), and Alex Justiss (41TT13) sites in the Big Cypress Creek basin (Figure 1).

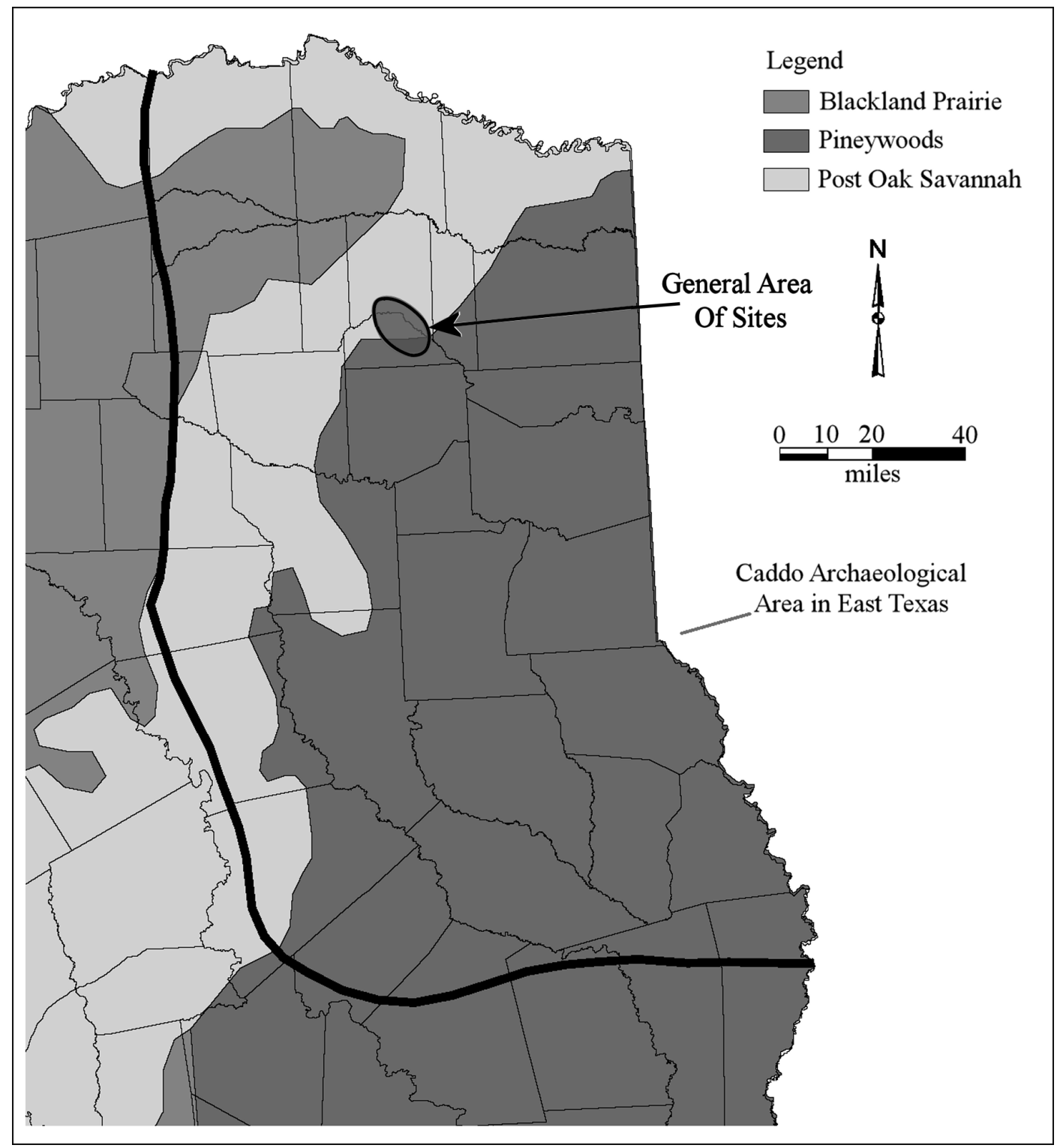

Figure 1. Location of the G. W. Rumsey (41CP3), Tuck Carpenter (41CP5), Harold Williams (41CP10), B. J. Horton (41CP20), and Alex Justiss (41TT13) sites in the Big Cypress Creek basin in East Texas. 


\section{Vessel Documentation}

To facilitate the vessel documentation and aid in comparisons with other Caddo vessel documentation projects, we established a documentation protocol several years ago to assist in the analysis of each of the vessels from the different sites. Each of the ceramic vessels in the collections is described and analyzed utilizing a consistent set of morphological, functional, and stylistic attributes. The purpose of the documentation is to thoroughly characterize the character of each of the ceramic vessels in the different Caddo collections. The sections that follow provide the completed vessel recordation forms for 38 Caddo vessels from five ancestral Caddo sites in East Texas (see Figure 1), as well as accompanying vessel photographic illustrations.

The following attributes were employed in the ceramic vessel study:

Non-plastics: Deliberate and indeterminate materials in the paste (Rice 1987:411), including a variety of tempers (grog or crushed sherds, bone, hematite, shell, quartz sands, etc.) and "particulate matter of some size." The grog, bone, and hematite non-plastics appear to have been deliberately added to the paste as tempers. The bone used for temper had been burned and calcined, then crushed, before it was added to the paste.

Vessel Form: The principal vessel form categories include open containers (bowls, carinated bowls, and compound bowls) and restricted containers, including jars and bottles of several shapes and sizes. As restricted containers, jars allow access by hand, but bottles do not (Brown 1996:335). Another important vessel form, at least in burial contexts, is the effigy bowl with a modeled head (usually a bird or duck head) and a tab tail. Occasionally, an effigy vessel will have a broader tab tail that supported an anthropomorphic or zoomorphic tail rider (see Suhm and Jelks 1962:Plate 24k).

Additional form attributes that were recorded on each of the vessels (depending upon their completeness) include the rim profile (outflaring or everted, vertical or standing, and inverted), lip profile (rolled to the exterior, rounded, flat, or thinned), and base shape (flat or rounded).

Core Colors: Observations on ceramic cross-section colors permit consideration of oxidation patterns (Teltser 1993:Figure 2A-H; Perttula 2005, ed.), and thus the conditions under which the vessel was fired and then cooled after firing. Comments are included for these attributes on the presence and location of fire-clouding, sooting or smudging from cooking use (Skibo 1992), and the preservation and location of charred organic remains or residues.

Wall Thickness: Thickness was recorded in millimeters, using a vernier caliper, at the lip, along the rim, at several points along the body, and at the base when possible (only for the vessels that were not complete).

Interior and Exterior Surface Treatment: The primary methods of finishing the surface of the vessel include smoothing, burnishing, and polishing (Rice 1987:138), although polishing is generally rarely seen on burial vessels. Brushing is a popular method of roughening the surface (particularly the body) of large and small Middle Caddo (ca. A.D. 1200-1400) and Late Caddo (ca. A.D. 1400-1680) period cooking jars and other utility wares, as well as Historic Caddo sites (post-A.D. 1680) in certain parts of East Texas. Here it is considered a decorative treatment rather than solely a functional surface treatment (cf. Rice 1987:138), although not all Caddo ceramic analysts treat brushing as a decorative treatment (cf. Gadus et al. 2006:31). In certain fine ware vessels, brushed bodies accompanied engraved rim panels. Smoothing creates "a finer and more regular surface... [and] has a matte rather than a lustrous finish" (Rice 
1987:138). Burnishing, on the other hand, creates an irregular lustrous finish marked by parallel facets left by the burnishing tool (perhaps a pebble or bone). A polished surface treatment is marked by a uniform and highly lustrous surface finish, done when the vessel is dry, but without "the pronounced parallel facets produced by burnishing leather-hard clay" (Rice 1987:138).

The application of a hematite-rich clay slip (Ferring and Perttula 1987), either red or black after firing in an oxidizing or reducing (i.e., low-oxygen) environment, is another form of surface treatment noted in these vessel assemblages, albeit very rarely. The clay slip is more frequently applied on the vessel exterior than on the interior surface, and then was either burnished or polished after it was leather-hard or dry.

Height and Orifice Diameter: These attributes, measured in centimeters, were recorded with a ruler.

Diameter at Bottom of Rim and Base Diameter: Also recorded in millimeters using a ruler, these attributes permit characterization of the overall contour and shape of the vessel. With bottles, we also obtained measurements of their maximum body diameter.

Volume: Previously, vessel volume in liters was determined by filling (to within $1 \mathrm{~mm}$ of the lip) the vessel with lentil seeds, then dumping the lentil seeds in containers of known volume. However, given the large number of Caddo vessels that have been measured over the years and volumes established, where measurements of height and orifice diameter were be obtained, volumes were estimated by comparison with known vessel volumes of specific forms (i.e., carinated bowl, jar, bottle, compound bowl, and bowl) in other documented Caddo vessel assemblages.

Decoration: Decorative techniques present in the vessel collections include engraving and excising, incising, punctating, pinching, lip notching, brushing, neck banding, and appliquéing. On certain vessels, primarily the utility wares, combinations of decorative techniques (i.e., brushed-punctated) created the decorative elements and motifs. Engraving and lip notching were done with a sharp tool when the vessel was either leather-hard, or after it was fired, while the other decorative techniques were executed with tools (incising and punctation), by adding strips of clay to the wet body (appliqué), by crimping the coils (neck banding), using frayed sticks or grass stems (brushing) dragged across the body surface, or fingernails (certain forms of punctations and pinching), when the vessel was wet or still plastic. Excising is considered a form of engraved decoration, where the clay is deliberately and closely marked/scraped and carved away with a sharp tool, usually to create triangular elements (the pendant triangle or small tick marks), negative elements, or crescent-shaped elements or brackets that separate or serve to define scrolls (Suhm and Jelks 1962:Plate 64a-b, f).

A red clay film or wash was added to the surface (interior and/or exterior surfaces) of some vessels as a slip before they were fired. Another form of vessel decoration is the use of red (hematite or ochre) or white (kaolin clay) clay pigments that have been smeared, impressed, or rubbed into the engraved lines of certain vessels.

Type: The kinds of named ceramic types in these collections follow primarily the work of Suhm and Jelks (1962); Mockingbird Punctated is defined in Perttula and Selden (2014). A series of varieties of Ripley Engraved have also been defined that follow closely the engraved motifs illustrated by Thurmond (1990:Figure 6), and depend upon his ceramic vessel classifications of more than 740 Ripley Engraved carinated bowls and compound bowls in the Big Cypress Creek basin (Figure 2). Turner Engraved has also been recently defined in the Titus phase vessel collections from several sites in the Big Cypress Creek basin (Figure 3). 

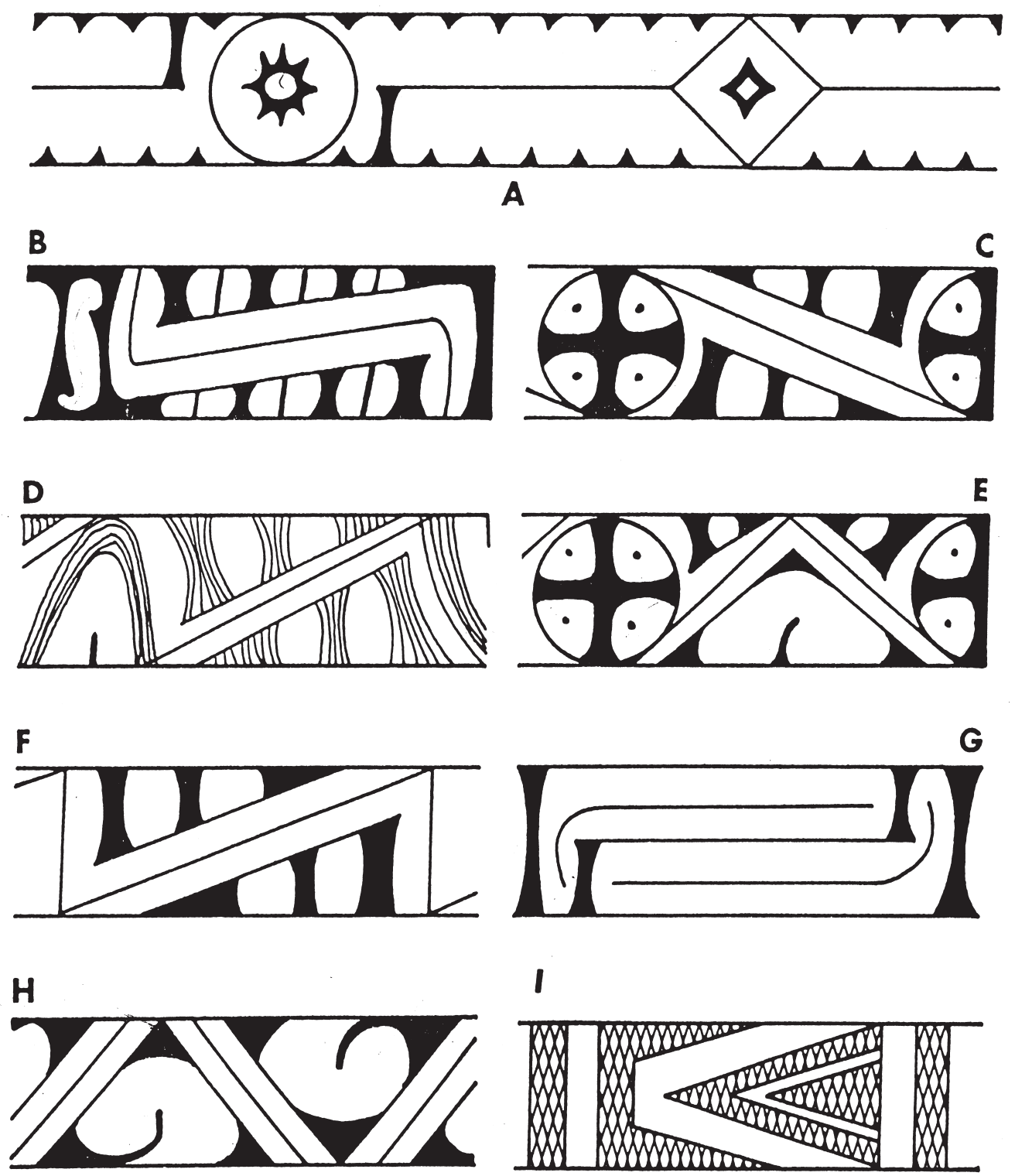

I
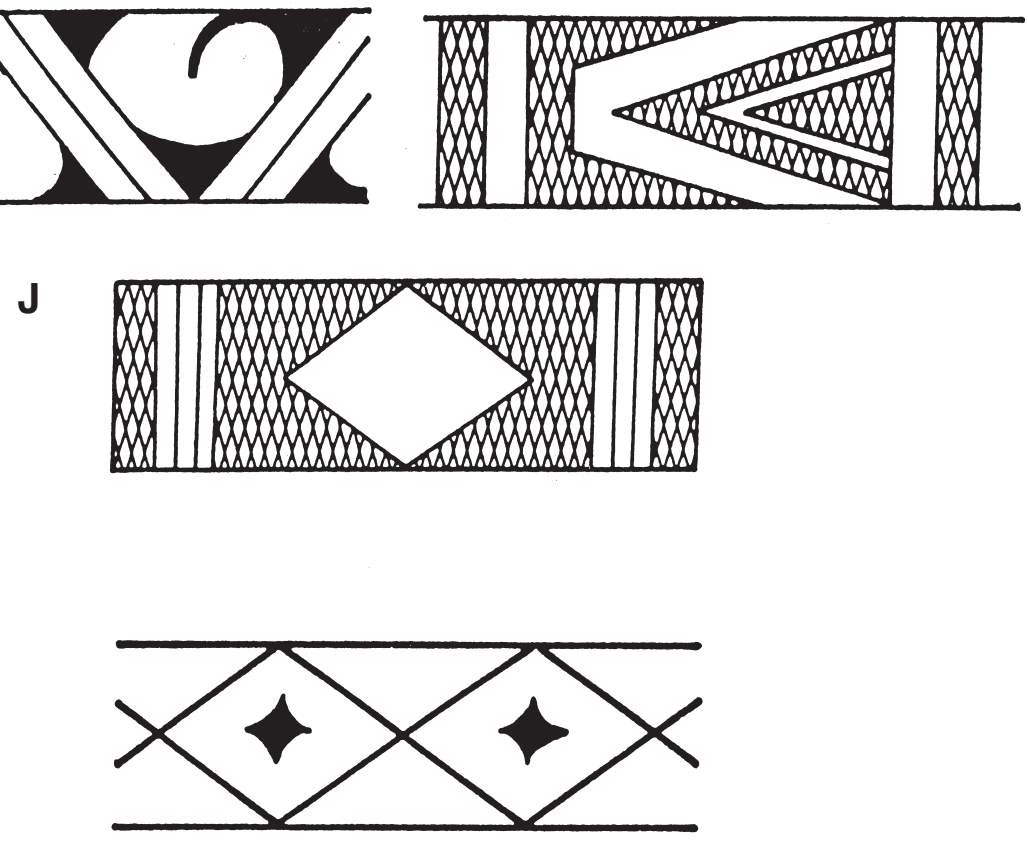

Figure 2. Varieties of Ripley Engraved carinated bowls and compound bowls: a, var. McKinney; b, var. Gandy; c, var. Galt; d, var. Caldwell; e, var. Cash; f, var. Carpenter; g, var. Pilgrims; h, var. Williams; i, k, var. unspecified; $\mathrm{j}$, var. Reed. 


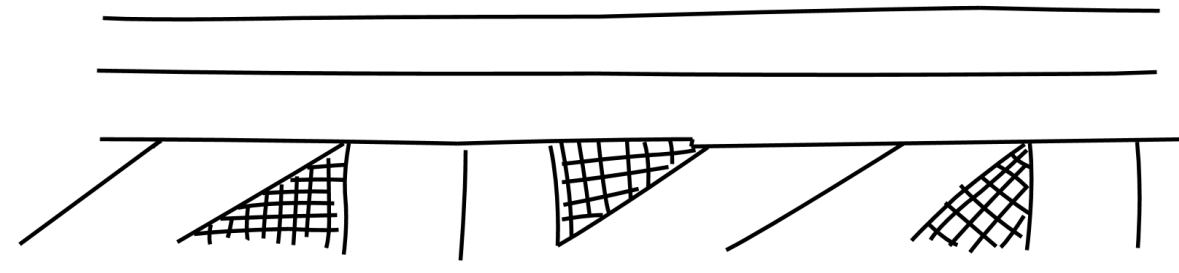

a

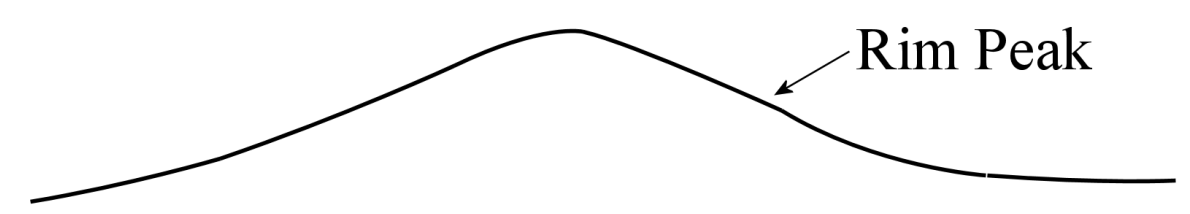

b
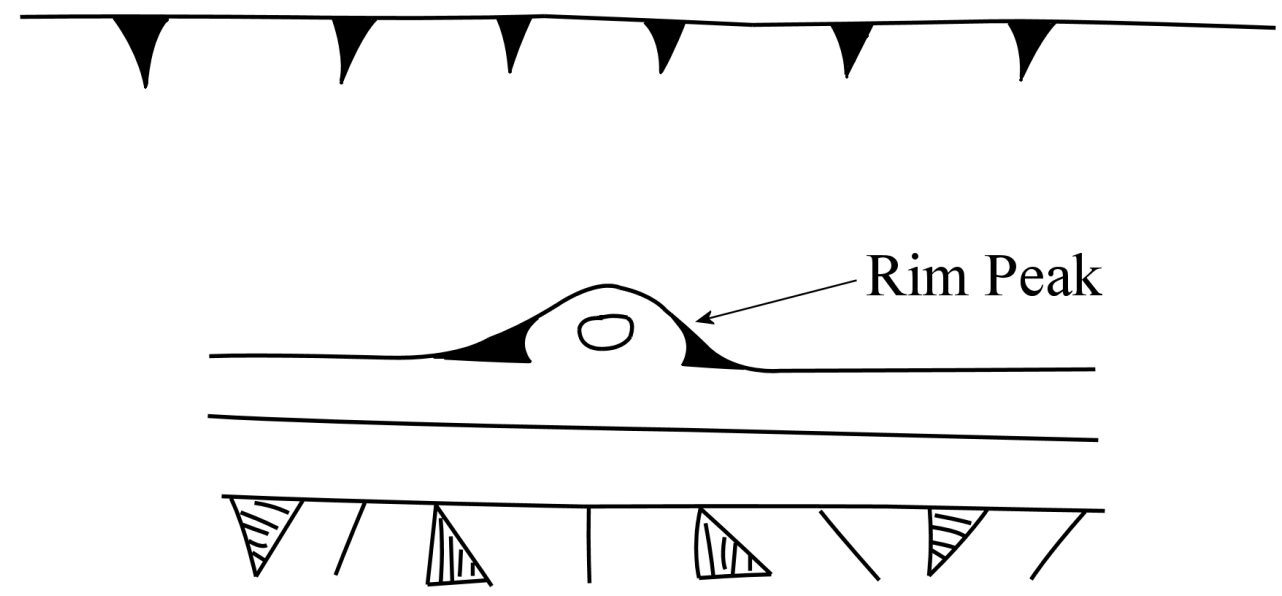

C
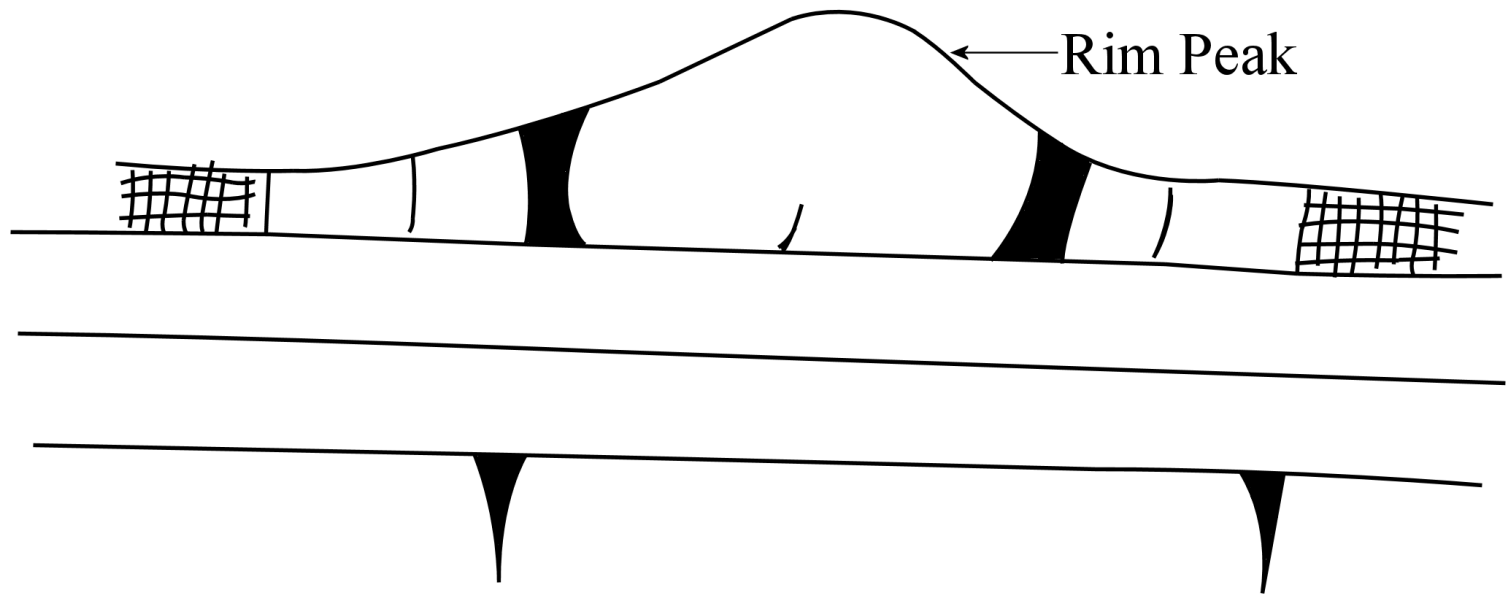

Figure 3. Turner Engraved varieties: a-b, var. Turner; c-d, var. Horton. 


\section{G. W. Rumsey Site (41CP3)}

The G. W. Rumsey site is on Greasy Creek, across the creek from the Late Caddo Titus phase mound center and large community cemetery at the Shelby Mound site (41CP71) (Perttula and Nelson 2004; Perttula et al. 2010:Figure 6). The site has both extensive Late Caddo habitation/midden deposits (Thurmond 1990:139), and Caddo burials of both Middle Caddo (see Turner 1997) and Late Caddo, Titus phase, age. The cemetery area is reported to be approximately $30 \mathrm{~m}$ from the thick Titus phase midden deposits (Thurmond 1990:139).

SITE NAME OR SITE NUMBER: G. W. Rumsey

VESSEL NO.: 21

VESSEL FORM: Carinated bowl

NON-PLASTICS AND PASTE: grog

RIM AND LIP FORM: Direct rim and rounded lip

CORE COLOR: F (fired in a reducing environment and cooled in the open air)

INTERIOR SURFACE COLOR: brown

EXTERIOR SURFACE COLOR: brown

WALL THICKNESS (IN MM): rim, $6.0 \mathrm{~mm}$; body, 6.5

$\mathrm{mm}$; base, $8.4 \mathrm{~mm}$

INTERIOR SURFACE TREATMENT: burnished

EXTERIOR SURFACE TREATMENT: burnished

HEIGHT (IN CM): N/A; rim height is $4.2 \mathrm{~cm}$

ORIFICE DIAMETER (IN CM): 27.0

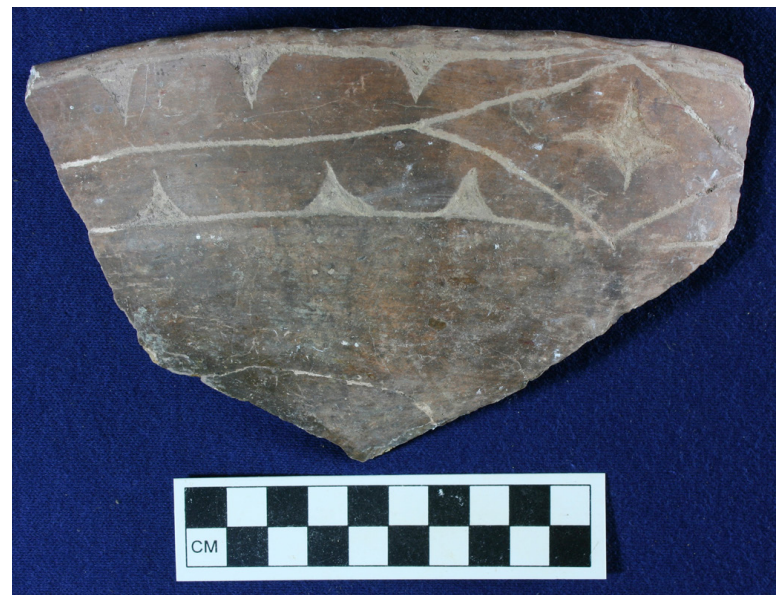

Figure 4. Ripley Engraved, var. McKinney carinated bowl from the G. W. Rumsey site.

DIAMETER AT BOTTOM OF RIM OR NECK (IN CM): 26.8

BASE DIAMETER (IN CM) AND SHAPE OF BASE: 8.0; circular and flat

ESTIMATED VOLUME (IN LITERS): N/A

DECORATION (INCLUDING MOTIF AND ELEMENTS WHEN APPARENT): The rim panel has an engraved horizontal scroll motif with alternating central circle and diamond elements repeating twice around the vessel. The horizontal scrolls end in excised brackets. Above and below the scrolls are single rows of excised pendant triangles. Both the central circle and diamond elements have smaller central excised circles with excised rays (Figure 4). There is also a single horizontal engraved line on the vessel interior at the carination.

PIGMENT USE AND LOCATION ON VESSEL: none

TYPE AND VARIETY (IF KNOWN): Ripley Engraved, var. McKinney 
SITE NAME OR SITE NUMBER: G. W. Rumsey

VESSEL NO.: 63

VESSEL FORM: Compound bowl

NON-PLASTICS AND PASTE: grog

RIM AND LIP FORM: Everted rim and a rounded lip

CORE COLOR: B (fired and cooled in a reducing environment)

INTERIOR SURFACE COLOR: grayish-brown; fire clouds on the rim, body, and base

EXTERIOR SURFACE COLOR: grayish-brown; fire clouds on the rim, body, and base

WALL THICKNESS (IN MM): rim, $7.2 \mathrm{~mm}$; body, $7.5 \mathrm{~mm}$; base, $14.0 \mathrm{~mm}$

INTERIOR SURFACE TREATMENT: smoothed

EXTERIOR SURFACE TREATMENT:

smoothed

HEIGHT (IN CM): N/A; rim height, $8.0 \mathrm{~cm}$

ORIFICE DIAMETER (IN CM): 38.0

DIAMETER AT BOTTOM OF RIM OR NECK

(IN CM): 38.5

BASE DIAMETER (IN CM) AND SHAPE OF

BASE: 10.0; circular and flat

ESTIMATED VOLUME (IN LITERS): N/A

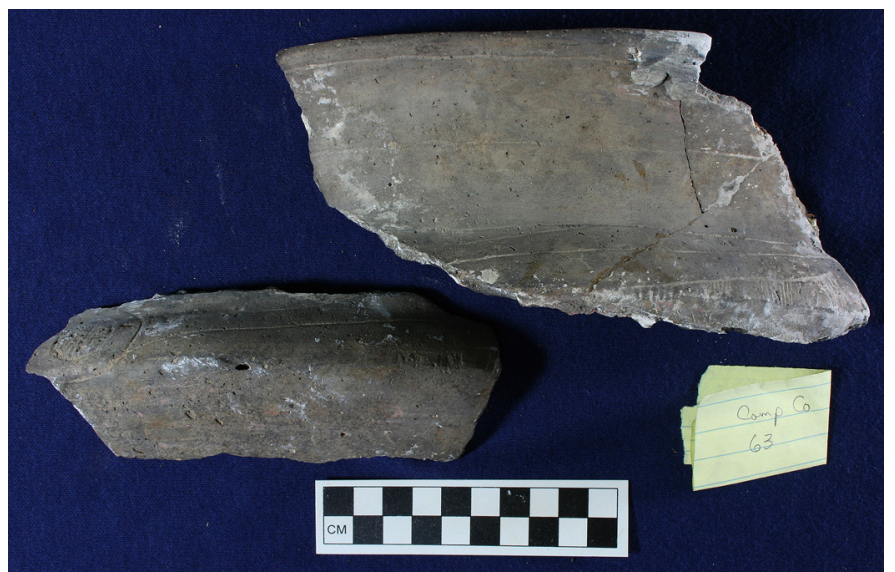

Figure 5. Ripley Engraved, var. Galt compound bowl from the G. W. Rumsey site.

DECORATION (INCLUDING MOTIF AND ELEMENTS WHEN APPARENT): The upper rim panel has two horizontal engraved lines. The lower rim panel has an engraved scroll and circle motif repeated four times around the vessel. The central circle elements have inner circles that are either filled with small circular excised punctates or completely excised. The upper and lower scroll fill zones have cross-hatched and vertical lines and brackets around negative ovals and vertical columns (Figure 5).

PIGMENT USE AND LOCATION ON VESSEL: none

TYPE AND VARIETY (IF KNOWN): Ripley Engraved, var. Galt 
SITE NAME OR SITE NUMBER: G. W. Rumsey

VESSEL NO.: NAGPRA 2012.1.97

VESSEL FORM: Jar with a short rim

NON-PLASTICS AND PASTE: grog

RIM AND LIP FORM: Everted rim and rounded lip

CORE COLOR: $\mathrm{G}$ (fired in a reducing environment and cooled in the open air)

INTERIOR SURFACE COLOR: yellowish-brown; fire clouds

EXTERIOR SURFACE COLOR: dark brown to black

WALL THICKNESS (IN MM): rim, $6.9 \mathrm{~mm}$; body, $7.8 \mathrm{~mm}$

INTERIOR SURFACE TREATMENT: smoothed

EXTERIOR SURFACE TREATMENT: smoothed only near the base

HEIGHT (IN CM): N/A

ORIFICE DIAMETER (IN CM): 13.5

DIAMETER AT BOTTOM OF RIM OR NECK (IN CM): 11.5

BASE DIAMETER (IN CM) AND SHAPE OF BASE: N/A

ESTIMATED VOLUME (IN LITERS): N/A

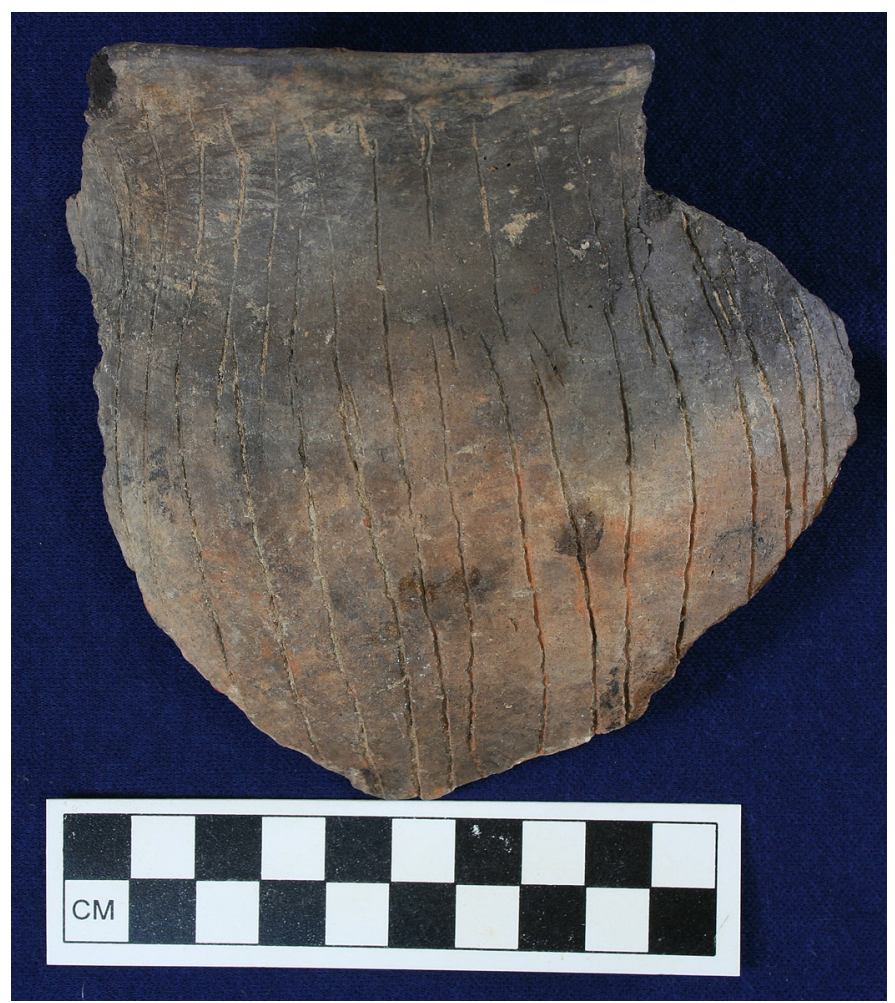

Figure 6. Incised jar from the G. W. Rumsey site.

DECORATION (INCLUDING MOTIF AND ELEMENTS WHEN APPARENT): The rim and the body are decorated with a continuous series of parallel vertical incised lines (Figure 6).

PIGMENT USE AND LOCATION ON VESSEL: none

TYPE AND VARIETY (IF KNOWN): Unidentified utility ware 
SITE NAME OR SITE NUMBER: G. W. Rumsey

VESSEL NO.: NAGPRA 2012.1.586

VESSEL FORM: Carinated bowl

NON-PLASTICS AND PASTE: grog and bone

RIM AND LIP FORM: Direct rim and a rounded, exterior folded lip

CORE COLOR: $\mathrm{F}$ (fired in a reducing environment and cooled in the open air)

INTERIOR SURFACE COLOR: yellowishbrown; fire clouds on the rim and body

EXTERIOR SURFACE COLOR:

yellowish-brown

WALL THICKNESS (IN MM): rim, 4.9 $\mathrm{mm}$; body, $6.3 \mathrm{~mm}$

INTERIOR SURFACE TREATMENT: smoothed

EXTERIOR SURFACE TREATMENT: smoothed

HEIGHT (IN CM): N/A; rim height, $6.9 \mathrm{~cm}$

ORIFICE DIAMETER (IN CM): 22.0

DIAMETER AT BOTTOM OF RIM OR NECK (IN CM): N/A

BASE DIAMETER (IN CM) AND SHAPE OF BASE: N/A

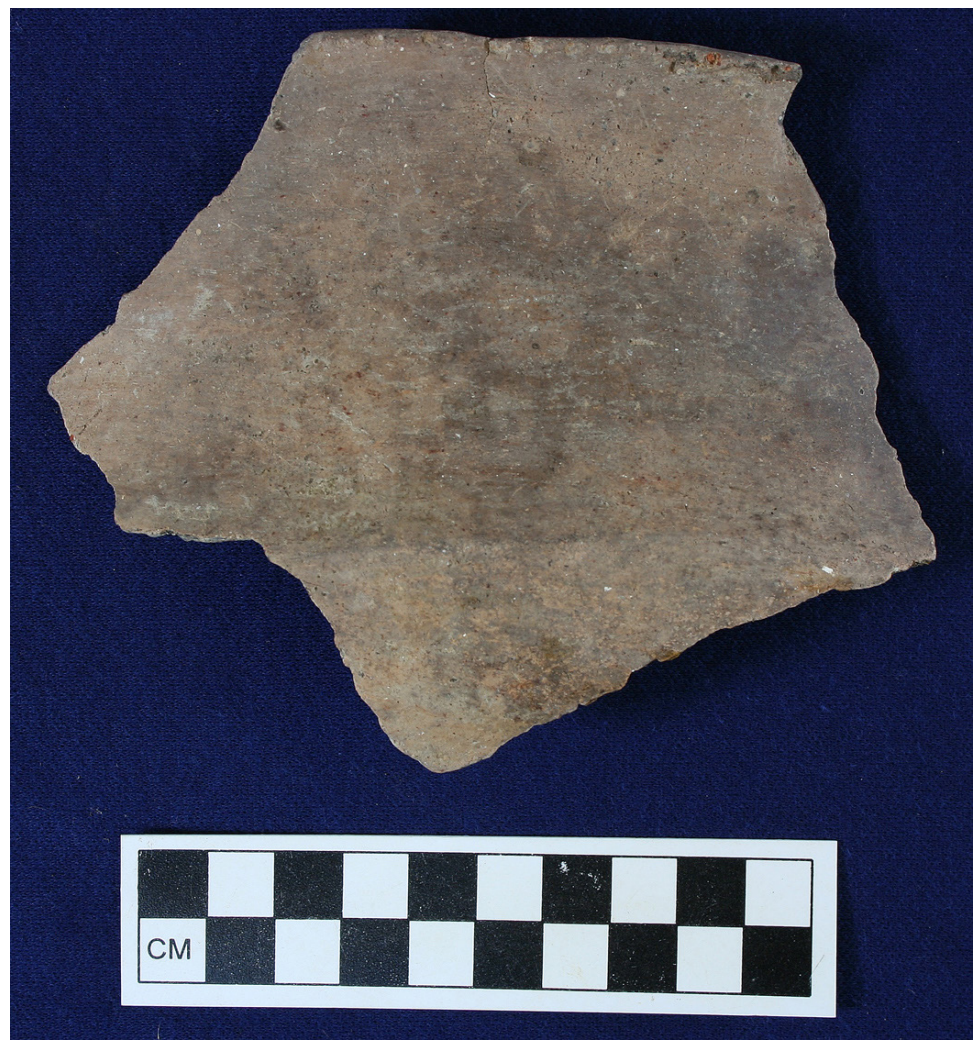

Figure 7. Plain carinated bowl from the G. W. Rumsey site.

ESTIMATED VOLUME (IN LITERS): N/A

DECORATION (INCLUDING MOTIF AND ELEMENTS WHEN APPARENT): Plain (Figure 7); possible lip notching

PIGMENT USE AND LOCATION ON VESSEL: none

TYPE AND VARIETY (IF KNOWN): Unidentified plain ware 
SITE NAME OR SITE NUMBER: G. W. Rumsey

VESSEL NO.: 2012.1.587

VESSEL FORM: Jar

NON-PLASTICS AND PASTE: grog

RIM AND LIP FORM: Direct rim and a rounded, exterior folded lip

CORE COLOR: $\mathrm{G}$ (fired in a reducing environment and cooled in the open air)

INTERIOR SURFACE COLOR: dark brown to black

EXTERIOR SURFACE COLOR: light brown; fire clouds on the rim and body; organic residue on the rim and body

WALL THICKNESS (IN MM): rim, 6.4 mm; body, $7.0 \mathrm{~mm}$

INTERIOR SURFACE TREATMENT: smoothed

EXTERIOR SURFACE TREATMENT: none

HEIGHT (IN CM): N/A; rim height, $5.8 \mathrm{~cm}$

ORIFICE DIAMETER (IN CM): 19.5

DIAMETER AT BOTTOM OF RIM OR NECK (IN CM): 19.5

BASE DIAMETER (IN CM) AND SHAPE OF BASE: N/A

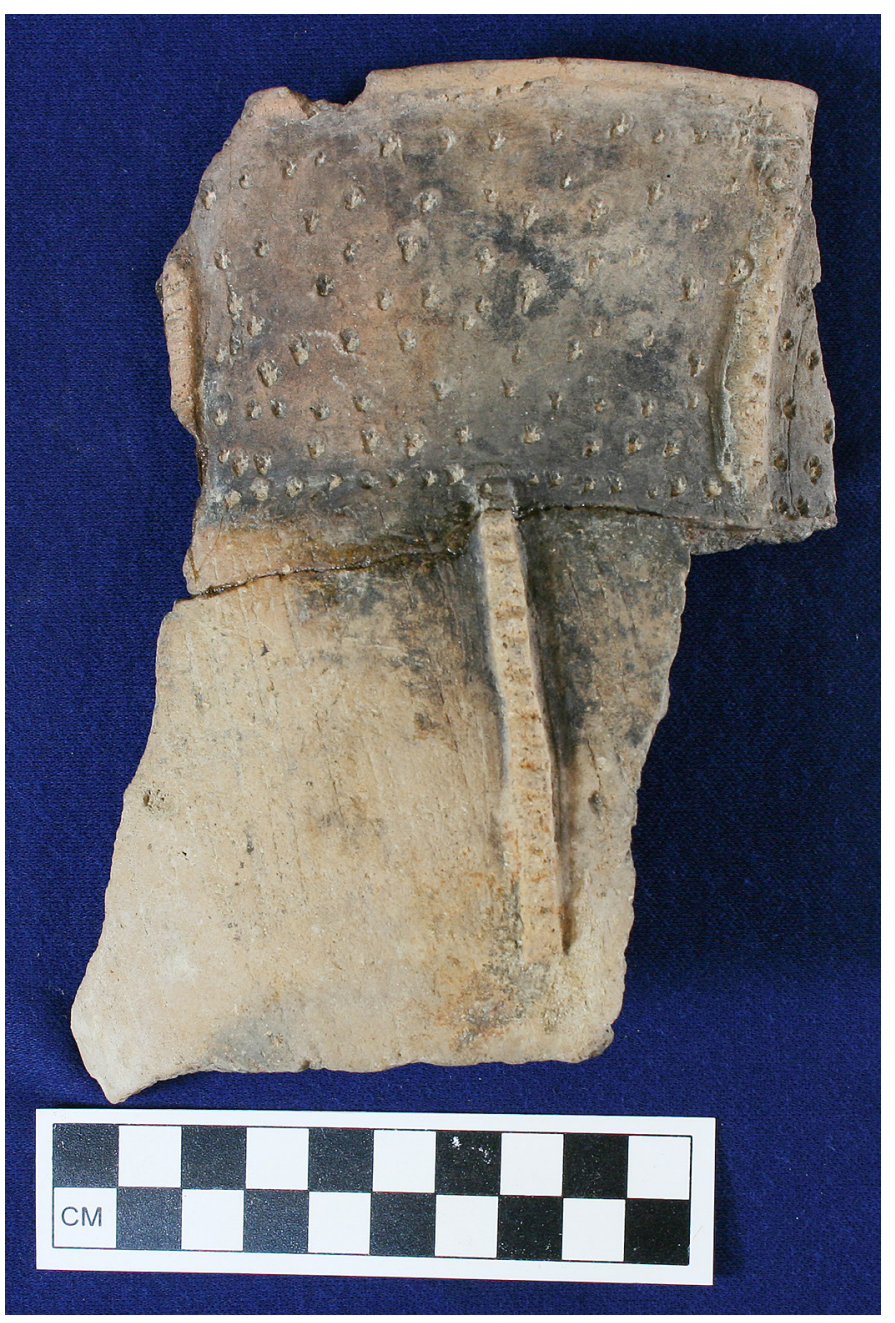

Figure 8. Appliqued-punctated jar from the G. W. Rumsey site.

\section{ESTIMATED VOLUME (IN LITERS): N/A}

DECORATION (INCLUDING MOTIF AND ELEMENTS WHEN APPARENT): The rim has at least eight rows of tool punctations, and these rows are divided by vertical appliqued fillets that extend from the lip to the rim-body juncture. The vessel body has vertical brushing marks divided into panels by vertical appliqued fillets (Figure 8).

PIGMENT USE AND LOCATION ON VESSEL: none

TYPE AND VARIETY (IF KNOWN): Unidentified utility ware 
SITE NAME OR SITE NUMBER: G. W. Rumsey

VESSEL NO.: 2012.1.588

VESSEL FORM: Carinated bowl

NON-PLASTICS AND PASTE: grog

RIM AND LIP FORM: Direct rim and a rounded, exterior folded lip

CORE COLOR: $\mathrm{G}$ (fired in a reducing environment and cooled in the open air)

INTERIOR SURFACE COLOR: dark brown to black

EXTERIOR SURFACE COLOR: brown; fire clouds

WALL THICKNESS (IN MM): rim, $7.5 \mathrm{~mm}$; body, $6.9 \mathrm{~mm}$

INTERIOR SURFACE TREATMENT: smoothed

EXTERIOR SURFACE TREATMENT: burnished

HEIGHT (IN CM): N/A; rim height, $5.8 \mathrm{~cm}$

ORIFICE DIAMETER (IN CM): 27.5

DIAMETER AT BOTTOM OF RIM OR NECK

(IN CM): 27.0

BASE DIAMETER (IN CM) AND SHAPE OF BASE: N/A

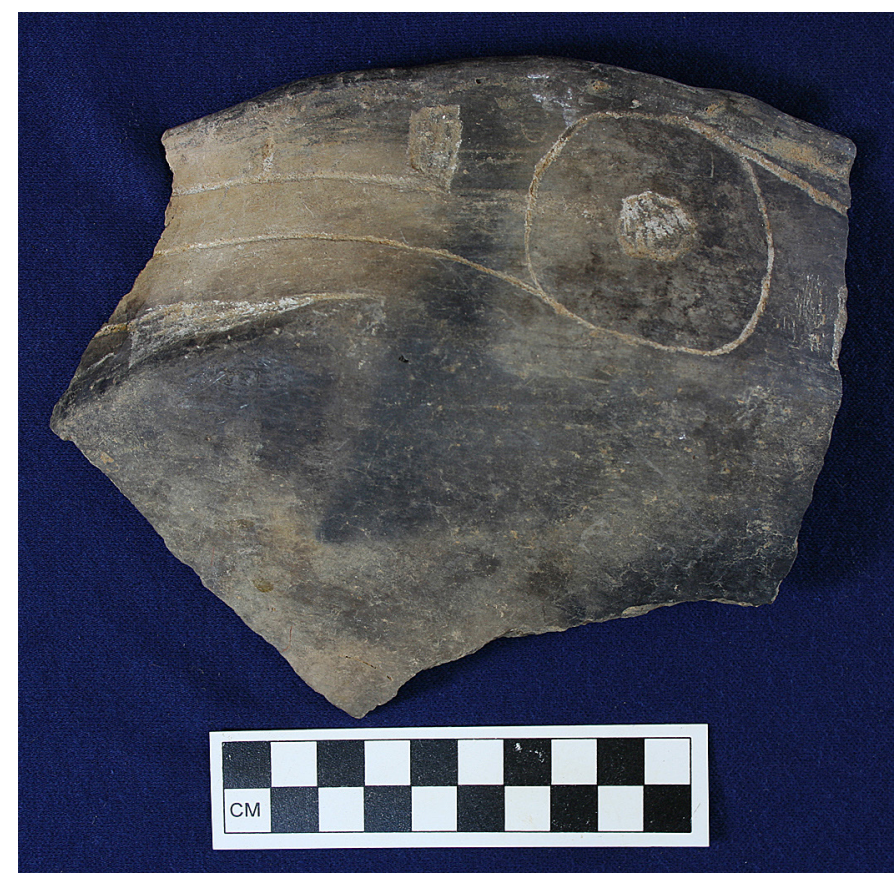

Figure 9. Ripley Engraved, var. Galt carinated bowl from the G. W. Rumsey site.

\section{ESTIMATED VOLUME (IN LITERS): N/A}

DECORATION (INCLUDING MOTIF AND ELEMENTS WHEN APPARENT): The rim panel has an engraved scroll and circle motif repeated around the vessel. The central circle element has a small inner excised circle. The upper and lower scroll fill zones have excised columns, vertical lines, and triangle elements (Figure 9).

PIGMENT USE AND LOCATION ON VESSEL: white in engraved lines

TYPE AND VARIETY (IF KNOWN): Ripley Engraved, var. Galt 


\section{Tuck Carpenter Site (41CP5)}

The Tuck Carpenter site (41CP5), on Dry Creek several miles from its confluence with Big Cypress Creek (see Perttula et al. 2010:Figure 6), is perhaps the best known Titus phase cemetery in the Big Cypress Creek basin. This is due to the careful analysis and reporting of the recovered funerary offerings and remains from 45 burials excavated by Turner and R. W. Walsh in the 1960s (Turner 1978, 1992). More than 95 percent of the graves had the bodies of single individuals laid in an extended supine position on the floor of the pit, but two burial features (Burials 21 and 23) had two individuals placed side by side in the burial pit

The Tuck Carpenter site is a large community cemetery that was apparently used for the interment of Caddo peoples for a considerable span of time in the 15th to the 17th century A.D. The burials were laid out in an east-west direction in a number of rows (Turner 1978:Figure 3), amidst an existing midden deposit. A wide assortment of funerary offerings were placed in the graves, including 402 ceramic vessels, eight ceramic pipes, four ceramic ear spools, two wood ear ornaments, one sandstone ear spool with a copper plate covering, one sandstone ear spool, 57 Talco arrow points, 19 Maud points, 55 Bassett points, 57 Perdiz point, one arrow point of unidentified type, one large chipped biface or Galt biface (Thurmond 1990:Table 23) of non-local chert (Thurmond 1990:144), one biface fragment, seven celts, one metate, four manos, four abrading stones, two polishing stones, one chipped gouge, deer mandibles, deer beamers, clay pigment masses, one marine shell columella bead, turtle carapaces, and mussel shells (Turner 1978:12-49). 
SITE NAME OR SITE NUMBER: Tuck Carpenter

VESSEL NO.: Burial 2, Pot 9

VESSEL FORM: Jar

NON-PLASTICS AND PASTE: grog

RIM AND LIP FORM: Everted rim and a rounded, exterior folded lip

CORE COLOR: $\mathrm{F}$ (fired in a reducing environment and cooled in the open air)

INTERIOR SURFACE COLOR: yellowish-brown; fire clouds on the rim and body

EXTERIOR SURFACE COLOR: yellowish-brown; fire clouds on the rim, body, and base

WALL THICKNESS (IN MM): rim, $7.3 \mathrm{~mm}$; body, $8.4 \mathrm{~mm}$

INTERIOR SURFACE TREATMENT: smoothed

EXTERIOR SURFACE TREATMENT: none

HEIGHT (IN CM): 13.0

ORIFICE DIAMETER (IN CM): 14.5

DIAMETER AT BOTTOM OF RIM OR NECK (IN CM): 12.5

BASE DIAMETER (IN CM) AND SHAPE OF BASE: $7.0 \mathrm{~cm}$; circular and flat

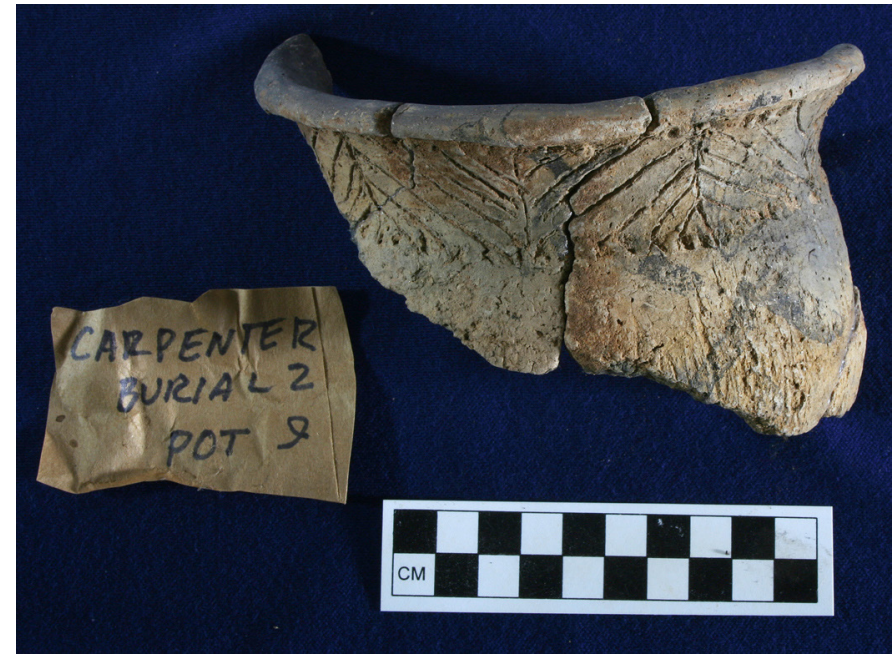

Figure 10. Maydelle Incised jar from Burial 2 (Pot 9) at the Tuck Carpenter site.

ESTIMATED VOLUME (IN LITERS): 1.1

DECORATION (INCLUDING MOTIF AND ELEMENTS WHEN APPARENT): The rim has single rows of tool punctates under the vessel lip and at the rim-body juncture. The remainder of the rim has five vertical incised panels filled with diagonal incised lines pitched in opposing directions. The vessel body has vertical brushing marks that extend from the rim-body juncture to the vessel base (Figure 10).

PIGMENT USE AND LOCATION ON VESSEL: none

TYPE AND VARIETY (IF KNOWN): Maydelle Incised 
SITE NAME OR SITE NUMBER: Tuck Carpenter

VESSEL NO.: Burial 9, Pot 1

VESSEL FORM: Jar with remnants of four rim peaks (Figure 11)

NON-PLASTICS AND PASTE: grog

RIM AND LIP FORM: Everted rim and rounded lip

CORE COLOR: $\mathrm{H}$ (fired in a reducing

environment and cooled in the open air)

INTERIOR SURFACE COLOR: grayish-brown

EXTERIOR SURFACE COLOR: yellowishbrown; fire clouds on the rim

WALL THICKNESS (IN MM): rim, $8.2 \mathrm{~mm}$; body, $8.6 \mathrm{~mm}$

INTERIOR SURFACE TREATMENT: smoothed

EXTERIOR SURFACE TREATMENT: none

HEIGHT (IN CM): 21.5

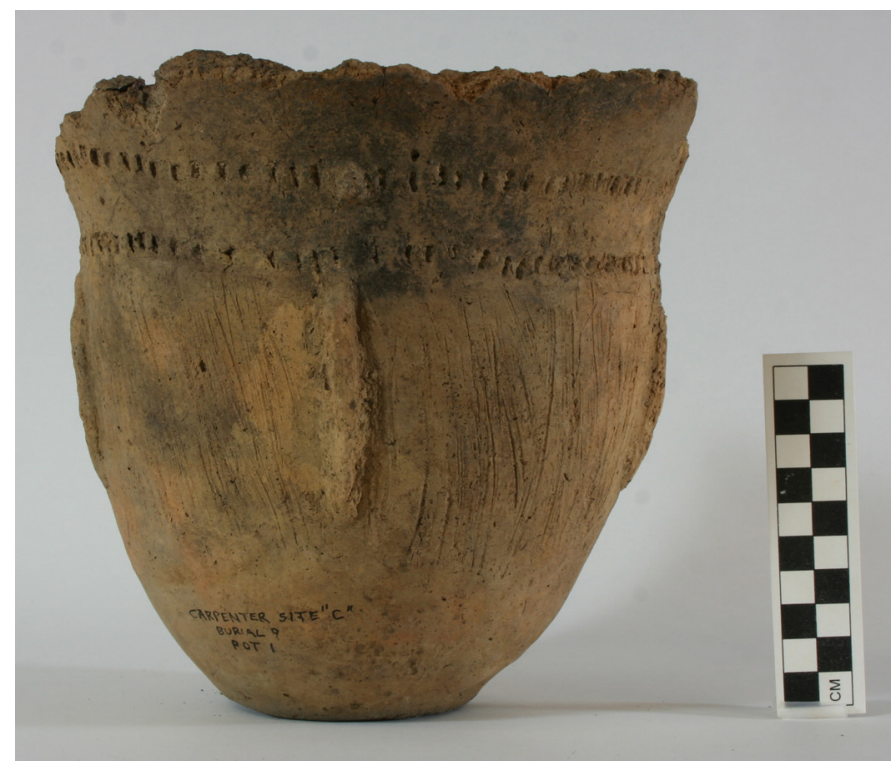

ORIFICE DIAMETER (IN CM): 20.8

Figure 11. Probable Pease Brushed-Incised jar from Burial 9 (Pot 1) at the Tuck Carpenter site.

DIAMETER AT BOTTOM OF RIM OR NECK (IN CM): 17.0

BASE DIAMETER (IN CM) AND SHAPE OF BASE: 7.5; circular and flat

\section{ESTIMATED VOLUME (IN LITERS): 3.7}

DECORATION (INCLUDING MOTIF AND ELEMENTS WHEN APPARENT): The rim is decorated with three rows of tool punctations and four rows of two appliqued nodes below each of the rim peaks. The topmost tool punctated row extends onto the rim peaks. The vessel body has four panels of vertical brushing marks defined by four vertical appliqued ridges. The brushing marks and appliqued ridges extend to within $7.0 \mathrm{~cm}$ of the vessel base.

PIGMENT USE AND LOCATION ON VESSEL: none

TYPE AND VARIETY (IF KNOWN): Unidentified utility ware, cf. Pease Brushed-Incised 
SITE NAME OR SITE NUMBER: Tuck Carpenter

VESSEL NO.: Burial 13, Pot 1

VESSEL FORM: Carinated bowl

NON-PLASTICS AND PASTE: grog

RIM AND LIP FORM: Direct rim and rounded, exterior folded lip

CORE COLOR: B (fired and cooled in a reducing environment)

INTERIOR SURFACE COLOR: dark grayish-brown

EXTERIOR SURFACE COLOR: very dark grayish-brown; fire clouds on the body

WALL THICKNESS (IN MM): $\operatorname{rim}, 7.3 \mathrm{~mm}$

INTERIOR SURFACE TREATMENT:

smoothed

EXTERIOR SURFACE TREATMENT:

burnished

HEIGHT (IN CM): 17.0

ORIFICE DIAMETER (IN CM): 31.0

DIAMETER AT BOTTOM OF RIM OR

NECK (IN CM): 31.2

BASE DIAMETER (IN CM) AND

SHAPE OF BASE: 9.5; circular and flat

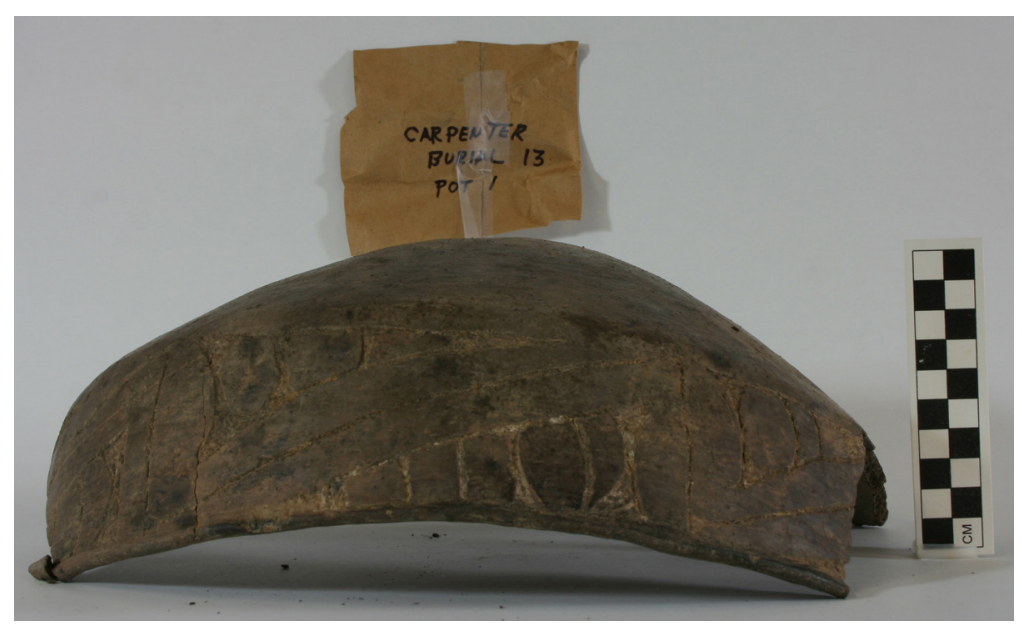

Figure 12. Ripley Engraved, var. Carpenter carinated bowl from Burial 13 (Pot 1) at the Tuck Carpenter site.

\section{ESTIMATED VOLUME (IN LITERS): 4.7}

DECORATION (INCLUDING MOTIF AND ELEMENTS WHEN APPARENT): The rim panel has an engraved continuous scroll motif that is repeated six times around the vessel. The upper part of each scroll line has a small excised triangle element. The upper and lower scroll fill zones have negative ovals and circles created by excised brackets, triangles, and curvilinear lines (Figure 12).

PIGMENT USE AND LOCATION ON VESSEL: white pigment in engraved lines

TYPE AND VARIETY (IF KNOWN): Ripley Engraved, var. Carpenter 
SITE NAME OR SITE NUMBER: Tuck Carpenter

VESSEL NO.: Burial 18, Pot 2

VESSEL FORM: Carinated bowl

NON-PLASTICS AND PASTE: grog

RIM AND LIP FORM: Direct rim and rounded, exterior folded lip

CORE COLOR: G (fired in a reducing environment and cooled in the open air)

INTERIOR SURFACE COLOR: dark yellowish-brown

EXTERIOR SURFACE COLOR: dark yellowish-brown

WALL THICKNESS (IN MM): rim, 6.6 $\mathrm{mm}$; body, $6.2 \mathrm{~mm}$; base, $6.2 \mathrm{~mm}$

INTERIOR SURFACE TREATMENT: smoothed

EXTERIOR SURFACE TREATMENT: burnished

HEIGHT (IN CM): N/A; rim height, 4.0 $\mathrm{cm}$

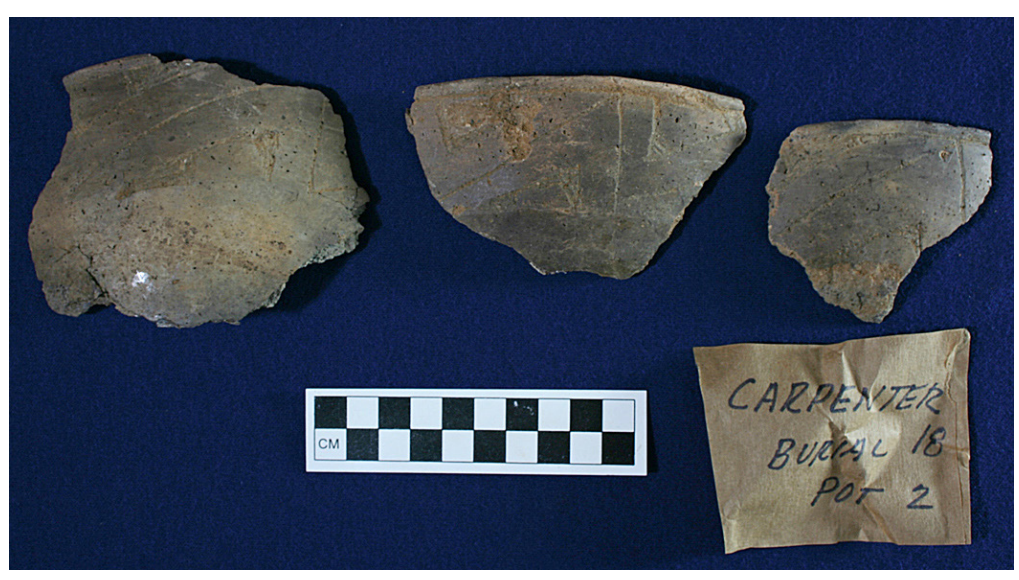

Figure 13. Ripley Engraved, var. Carpenter carinated bowl from Burial 18 (Pot 2) at the Tuck Carpenter site.

ORIFICE DIAMETER (IN CM): 20.0

DIAMETER AT BOTTOM OF RIM OR NECK (IN CM): 19.8

BASE DIAMETER (IN CM) AND SHAPE OF BASE: 6.8; circular and flat

ESTIMATED VOLUME (IN LITERS): N/A

DECORATION (INCLUDING MOTIF AND ELEMENTS WHEN APPARENT): The rim panel has an engraved continuous scroll motif that is repeated four times around the vessel. The upper and lower scroll fill zones have excised brackets and triangle elements, forming one large negative oval within the zones (Figure 13). There is also a single horizontal engraved line on the interior vessel surface at the carination.

PIGMENT USE AND LOCATION ON VESSEL: none

TYPE AND VARIETY (IF KNOWN): Ripley Engraved, var. Carpenter 
SITE NAME OR SITE NUMBER: Tuck Carpenter

VESSEL NO.: Burial 19, Pot 12

VESSEL FORM: Carinated bowl

NON-PLASTICS AND PASTE: grog

RIM AND LIP FORM: Direct rim and a rounded, exterior folded lip

CORE COLOR: F (fired in a reducing environment and cooled in the open air)

INTERIOR SURFACE COLOR: yellowish-brown; fire clouds on the rim, body, and base

EXTERIOR SURFACE COLOR: yellowish-

brown; fire clouds on the body and base

WALL THICKNESS (IN MM): rim, $7.5 \mathrm{~mm}$

INTERIOR SURFACE TREATMENT: burnished

EXTERIOR SURFACE TREATMENT:

burnished

HEIGHT (IN CM): 13.5

ORIFICE DIAMETER (IN CM): 27.6

DIAMETER AT BOTTOM OF RIM OR NECK

(IN CM): 27.3

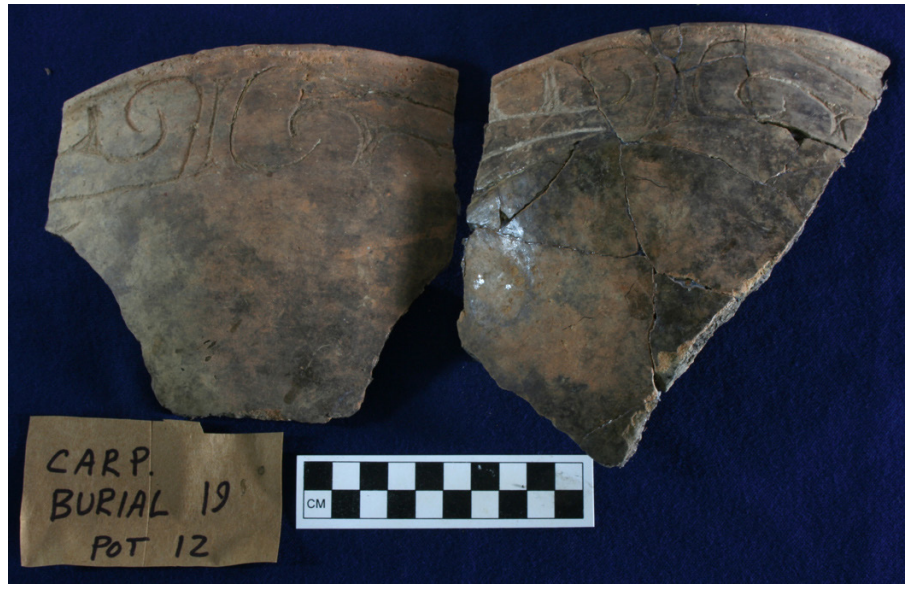

Figure 14. Ripley Engraved, var. unspecified carinated bowl from Burial 19 (Pot 12) at the Tuck Carpenter site.

BASE DIAMETER (IN CM) AND SHAPE OF BASE: 8.5; circular and flat

ESTIMATED VOLUME (IN LITERS): 3.4

DECORATION (INCLUDING MOTIF AND ELEMENTS WHEN APPARENT): The rim panel has alternating engraved circle elements (repeated twice) and excised bracket/hooked arm elements (repeated twice) around the vessel, connecting by a slanting scroll. The central circles have a smaller inner circle with excised crosses. The bracket elements are excised, and have hooked arms from the end of scrolls and scroll fill zones on either side. The upper and lower scroll fill zones have excised brackets, triangles, pendant triangles, and vertical lines, forming negative panels within the fill zones (Figure 14).

PIGMENT USE AND LOCATION ON VESSEL: white pigment in the engraved lines

TYPE AND VARIETY (IF KNOWN): Ripley Engraved, var. unspecified 
SITE NAME OR SITE NUMBER: Tuck Carpenter

VESSEL NO.: Burial 24, Pot 3

VESSEL FORM: Carinated bowl

NON-PLASTICS AND PASTE: grog

RIM AND LIP FORM: Direct rim and a rounded, exterior folded lip

CORE COLOR: B (fired and cooled in a reducing environment)

INTERIOR SURFACE COLOR: very dark grayish-brown

EXTERIOR SURFACE COLOR: very dark grayish-brown

WALL THICKNESS (IN MM): rim, $6.1 \mathrm{~mm}$; body, $5.9 \mathrm{~mm}$

INTERIOR SURFACE TREATMENT: smoothed; black slip

EXTERIOR SURFACE TREATMENT:

burnished; black slip

HEIGHT (IN CM): 13.1

ORIFICE DIAMETER (IN CM): 31.0

DIAMETER AT BOTTOM OF RIM OR

NECK (IN CM): 30.5

BASE DIAMETER (IN CM) AND

SHAPE OF BASE: 8.5 ; circular and flat

ESTIMATED VOLUME (IN LITERS):

3.6

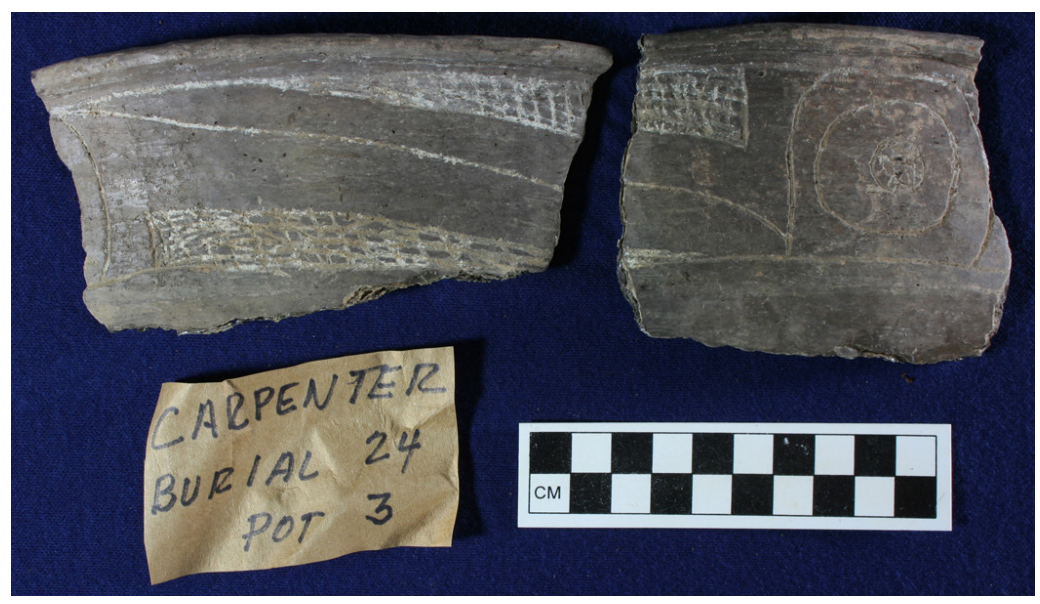

Figure 15. Ripley Engraved, var. Galt carinated bowl from Burial 24 (Pot 3) at the Tuck Carpenter site.

DECORATION (INCLUDING MOTIF AND ELEMENTS WHEN APPARENT): The rim panel has an engraved scroll and circle motif repeated four times around the vessel. The central circle elements have two inner central circles, the innermost fully excised. The upper and lower scroll fill zones are filled with crosshatched engraved lines (Figure 15).

PIGMENT USE AND LOCATION ON VESSEL: white pigment in the engraved lines

TYPE AND VARIETY (IF KNOWN): Ripley Engraved, var. Galt 
SITE NAME OR SITE NUMBER: Tuck Carpenter

VESSEL NO.: Burial 25, Pot 2

VESSEL FORM: Carinated bowl

NON-PLASTICS AND PASTE: grog

RIM AND LIP FORM: Direct rim and a rounded, exterior folded lip

CORE COLOR: $\mathrm{G}$ (fired in a reducing environment and cooled in the open air)

INTERIOR SURFACE COLOR: very dark brown

EXTERIOR SURFACE COLOR: dark yellowishbrown; fire clouds

WALL THICKNESS (IN MM): rim, 7.4 mm

INTERIOR SURFACE TREATMENT: burnished

EXTERIOR SURFACE TREATMENT:

burnished; black slip

HEIGHT (IN CM): 12.5

ORIFICE DIAMETER (IN CM): 28.0

DIAMETER AT BOTTOM OF RIM OR NECK

(IN CM): 27.6

BASE DIAMETER (IN CM) AND SHAPE OF

BASE: 8.5 ; circular and flat

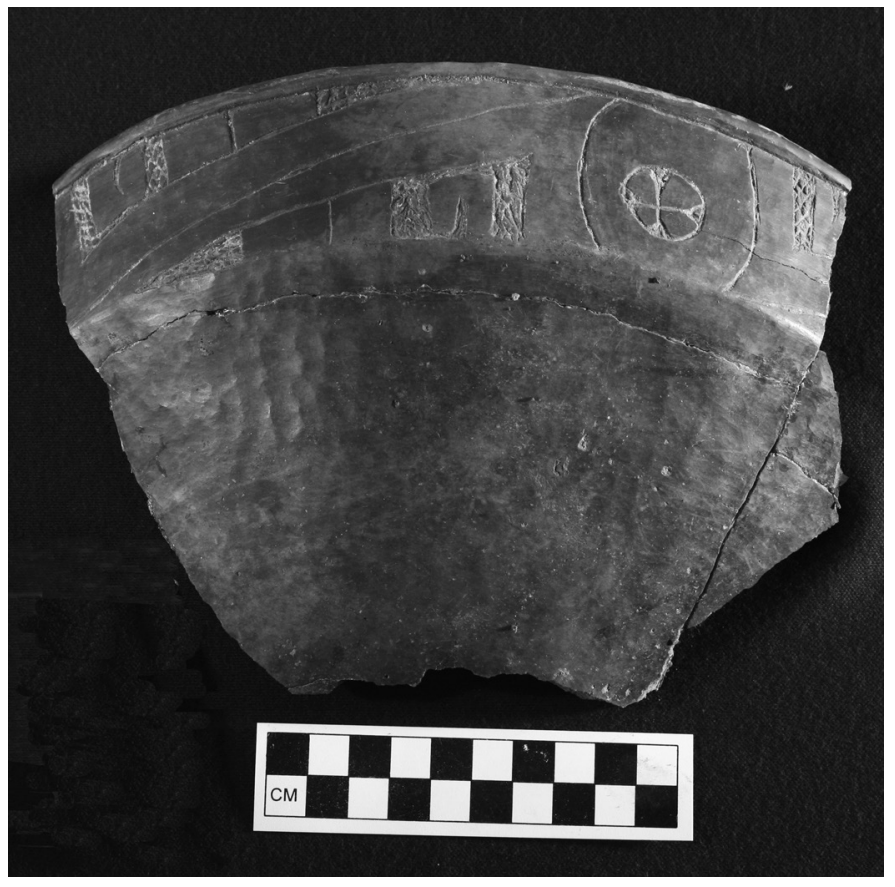

Figure 16. Ripley Engraved, var. Galt carinated bowl from Burial 25 (Pot 2) at the Tuck Carpenter site.

\section{ESTIMATED VOLUME (IN LITERS): 2.1}

DECORATION (INCLUDING MOTIF AND ELEMENTS WHEN APPARENT): The rim panel has an engraved scroll and circle motif repeated four times around the vessel. The central circle elements have a smaller inner central circle with crossed lines; the crossed lines have pendant hatched triangles. The upper and lower scroll fill zones have cross-hatched triangles and columns, excised triangles and columns, and excised vertical lines and small hooks in the open columns (Figure 16).

PIGMENT USE AND LOCATION ON VESSEL: white pigment in the engraved lines

TYPE AND VARIETY (IF KNOWN): Ripley Engraved, var. Galt 
SITE NAME OR SITE NUMBER: Tuck Carpenter

VESSEL NO.: Burial 25, Pot 9

VESSEL FORM: Bowl with plain tab tail (24 x 37 x $7.2 \mathrm{~mm}$ in length, width, and thickness) (Figure 17)

NON-PLASTICS AND PASTE: grog

RIM AND LIP FORM: Direct rim and rounded, exterior folded lip

CORE COLOR: $\mathrm{G}$ (fired in a reducing environment and cooled in the open air)

INTERIOR SURFACE COLOR: dark grayish-brown

EXTERIOR SURFACE COLOR: dark yellowish-brown

WALL THICKNESS (IN MM): rim, 4.4 $\mathrm{mm}$; body, $4.7 \mathrm{~mm}$; base, $6.3 \mathrm{~mm}$

INTERIOR SURFACE TREATMENT: smoothed

EXTERIOR SURFACE TREATMENT: smoothed

HEIGHT (IN CM): 5.1

ORIFICE DIAMETER (IN CM): 12.0

DIAMETER AT BOTTOM OF RIM OR NECK (IN CM): N/A

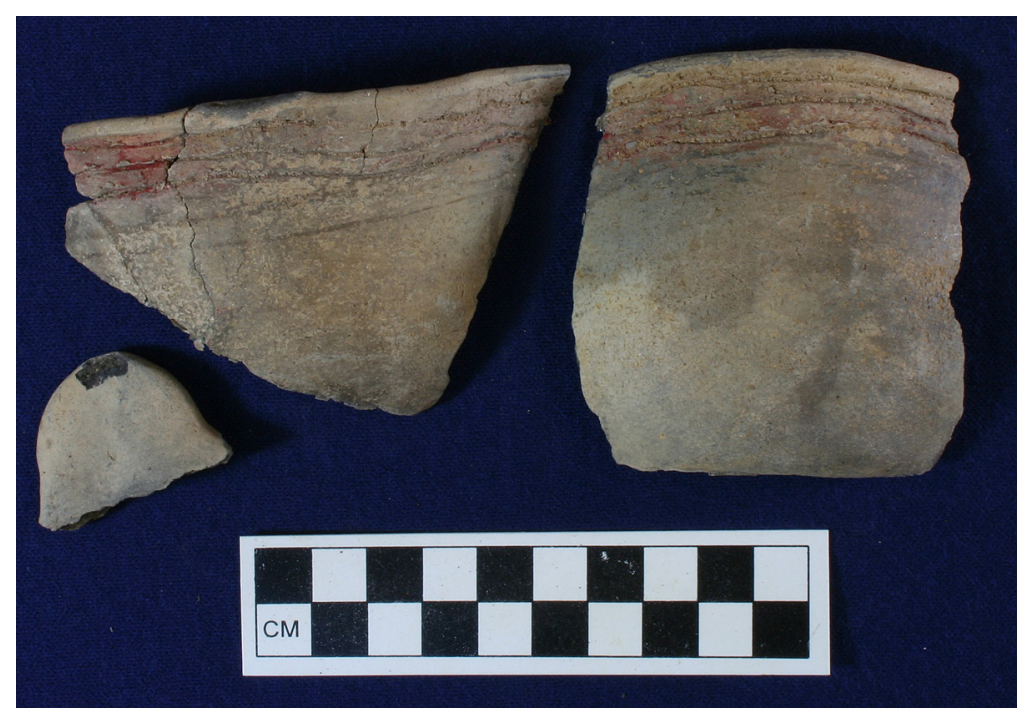

Figure 17. Incised bowl from Burial 25 (Pot 9) at the Tuck Carpenter site.

BASE DIAMETER (IN CM) AND SHAPE OF BASE: $4.4 \mathrm{~cm}$; circular and flat

ESTIMATED VOLUME (IN LITERS): 0.25

DECORATION (INCLUDING MOTIF AND ELEMENTS WHEN APPARENT): Three horizontal incised lines below the vessel lip (Figure 17)

PIGMENT USE AND LOCATION ON VESSEL: red clay pigment in the incised lines

TYPE AND VARIETY (IF KNOWN): Unidentified incised ware, cf. Hood Engraved, but with incised lines 
SITE NAME OR SITE NUMBER: Tuck Carpenter

VESSEL NO.: Burial 26, Pot 1

VESSEL FORM: Bowl

NON-PLASTICS AND PASTE: grog

RIM AND LIP FORM: Direct rim and a rounded lip

CORE COLOR: B (fired and cooled in a reducing environment)

INTERIOR SURFACE COLOR: very dark grayish-brown

EXTERIOR SURFACE COLOR: very dark grayish-brown

WALL THICKNESS (IN MM): rim, $4.1 \mathrm{~mm}$; body, $5.1 \mathrm{~mm}$; base, $7.4 \mathrm{~mm}$

INTERIOR SURFACE TREATMENT: smoothed

EXTERIOR SURFACE TREATMENT: burnished

HEIGHT (IN CM): 4.0

ORIFICE DIAMETER (IN CM): 9.0

DIAMETER AT BOTTOM OF RIM OR NECK (IN CM): N/A

BASE DIAMETER (IN CM) AND SHAPE OF BASE: 4.0; circular and flat

ESTIMATED VOLUME (IN LITERS): 0.15

DECORATION (INCLUDING MOTIF AND ELEMENTS WHEN APPARENT): The rim has an engraved scroll and circle motif repeated four times around the vessel. The central circle element has a small inner and centrally located excised dot. The upper and lower scroll fill zones have excised brackets, triangles, and vertical lines, creating open rectangular areas in the fill zones (Figure 18).

PIGMENT USE AND LOCATION ON VESSEL: white pigment in the engraved lines

TYPE AND VARIETY (IF KNOWN): Ripley Engraved, var. Galt

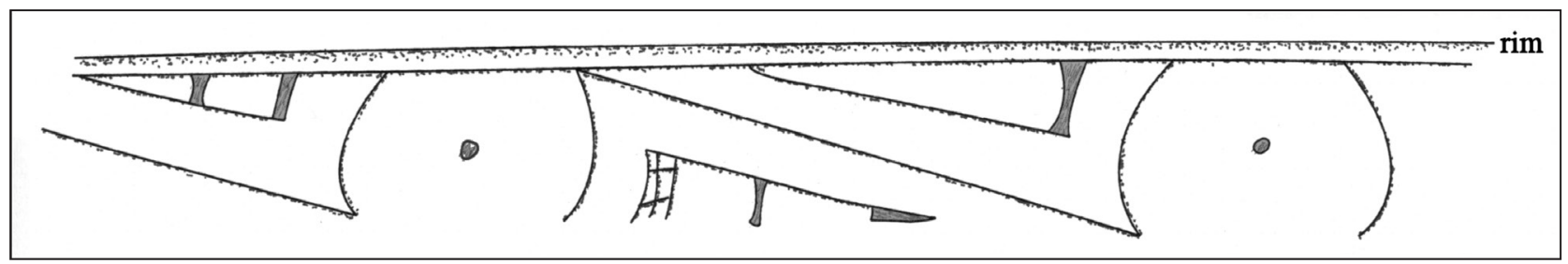

Figure 18. Engraved motif on Ripley Engraved, var. Galt bowl from Burial 26 (Pot 1) at the Tuck Carpenter site. 
SITE NAME OR SITE NUMBER: Tuck Carpenter

VESSEL NO.: Burial 30, Pot 5

VESSEL FORM: Jar

NON-PLASTICS AND PASTE: grog

RIM AND LIP FORM: Everted rim and rounded lip

CORE COLOR: $\mathrm{F}$ (fired in a reducing environment and cooled in the open air)

INTERIOR SURFACE COLOR: yellowish-brown; fire clouds on the rim and body; organic residue on the body

EXTERIOR SURFACE COLOR: yellowishbrown; fire clouds on the rim and body; organic residue on the rim and body

WALL THICKNESS (IN MM): rim, $8.7 \mathrm{~mm}$

INTERIOR SURFACE TREATMENT: smoothed

EXTERIOR SURFACE TREATMENT: none

HEIGHT (IN CM): 24.8

ORIFICE DIAMETER (IN CM): 22.4

DIAMETER AT BOTTOM OF RIM OR NECK (IN CM): 22.0

BASE DIAMETER (IN CM) AND SHAPE OF BASE: N/A

ESTIMATED VOLUME (IN LITERS): 7.2

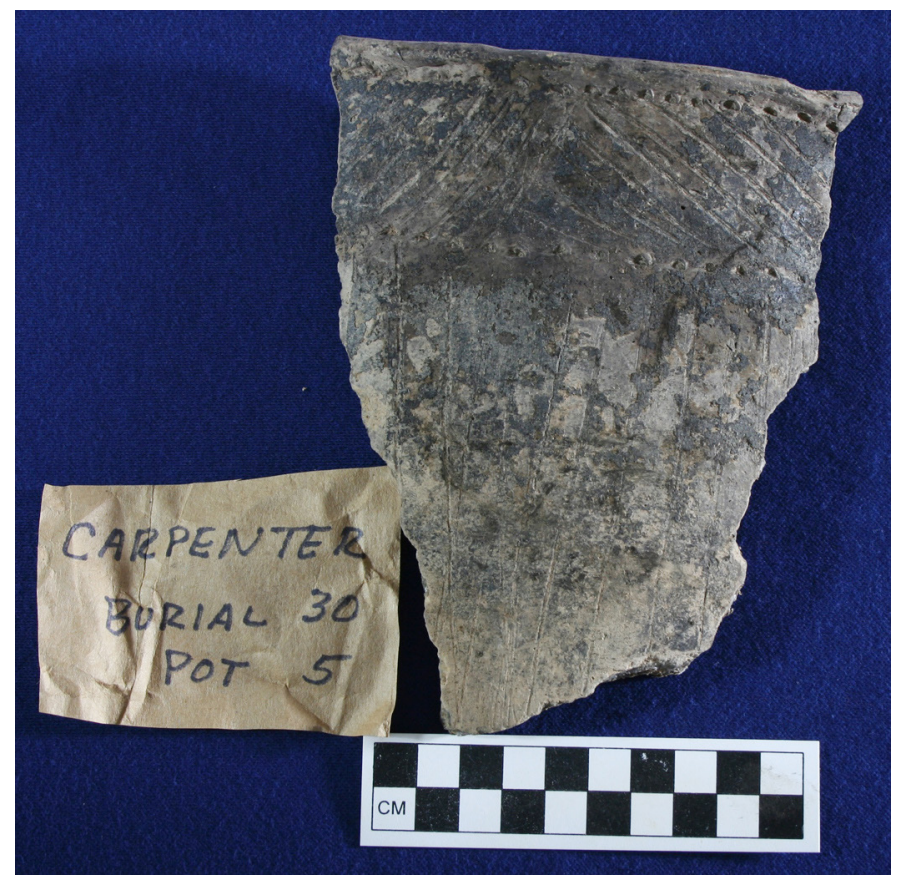

Figure 19. Maydelle Incised jar from Burial 30 (Pot 5) at the Tuck Carpenter site.

DECORATION (INCLUDING MOTIF AND ELEMENTS WHEN APPARENT): There are single horizontal rows of tool punctates under the lip and at the rim-body juncture. Between the punctated rows are diagonal opposed incised chevron elements repeated 12 times around the vessel. The vessel body is decorated with vertical incised lines that extend to within $9.0 \mathrm{~cm}$ of the base (Figure 19).

PIGMENT USE AND LOCATION ON VESSEL: none

TYPE AND VARIETY (IF KNOWN): Maydelle Incised 
SITE NAME OR SITE NUMBER: Tuck Carpenter

VESSEL NO.: Burial 33, Pot 6

VESSEL FORM: Jar

NON-PLASTICS AND PASTE: grog

RIM AND LIP FORM: Direct rim and a rounded, exterior folded lip

CORE COLOR: F (fired in a reducing environment and cooled in the open air)

INTERIOR SURFACE COLOR: yellowish-brown; fire clouds on the body and base; organic residue on the body

EXTERIOR SURFACE COLOR: yellowish-brown; fire clouds on the rim, body, and base; organic residue on the rim and body

WALL THICKNESS (IN MM): rim, $6.5 \mathrm{~mm}$; body, $7.8 \mathrm{~mm}$

INTERIOR SURFACE TREATMENT: smoothed

EXTERIOR SURFACE TREATMENT: smoothed on the lower body

HEIGHT (IN CM): 32.4

ORIFICE DIAMETER (IN CM): 25.5

DIAMETER AT BOTTOM OF RIM OR NECK (IN CM): 25.0

BASE DIAMETER (IN CM) AND SHAPE OF BASE: 8.5 ; circular and flat

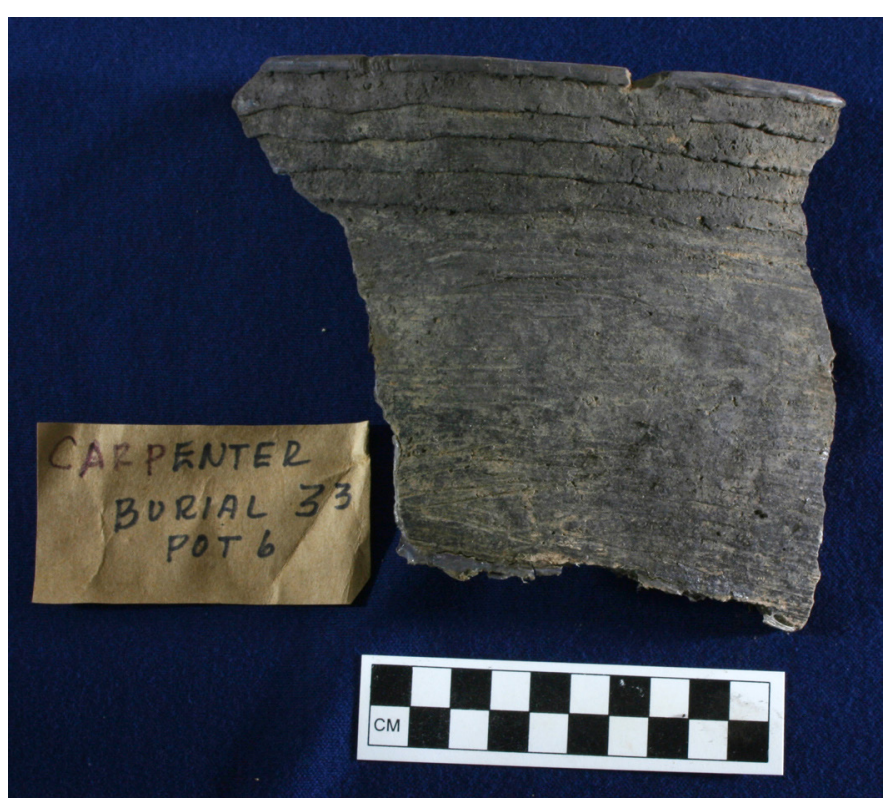

Figure 20. La Rue Neck Banded jar from Burial 33 (Pot 6) at the Tuck Carpenter site.

ESTIMATED VOLUME (IN LITERS): 10.7

DECORATION (INCLUDING MOTIF AND ELEMENTS WHEN APPARENT): The rim has four horizontal neck bands or corrugated coils. The vessel body has horizontal and overlapping brushed marks that extend to within $5.5 \mathrm{~cm}$ of the base (Figure 20).

PIGMENT USE AND LOCATION ON VESSEL: none

TYPE AND VARIETY (IF KNOWN): La Rue Neck Banded 
SITE NAME OR SITE NUMBER: Tuck Carpenter

VESSEL NO.: Burial 39, Pot 5

VESSEL FORM: Bottle

NON-PLASTICS AND PASTE: grog

RIM AND LIP FORM: Direct rim and a rounded lip

CORE COLOR: $\mathrm{G}$ (fired in a reducing environment and cooled in the open air)

INTERIOR SURFACE COLOR: very dark grayish-brown

EXTERIOR SURFACE COLOR: dark yellowishbrown

WALL THICKNESS (IN MM): rim, $4.8 \mathrm{~mm}$; body, $6.5 \mathrm{~mm}$; base, $8.8 \mathrm{~mm}$

INTERIOR SURFACE TREATMENT: none

EXTERIOR SURFACE TREATMENT: smoothed

HEIGHT (IN CM): N/A

ORIFICE DIAMETER (IN CM): 3.8

DIAMETER AT BOTTOM OF RIM OR NECK (IN CM): 3.5

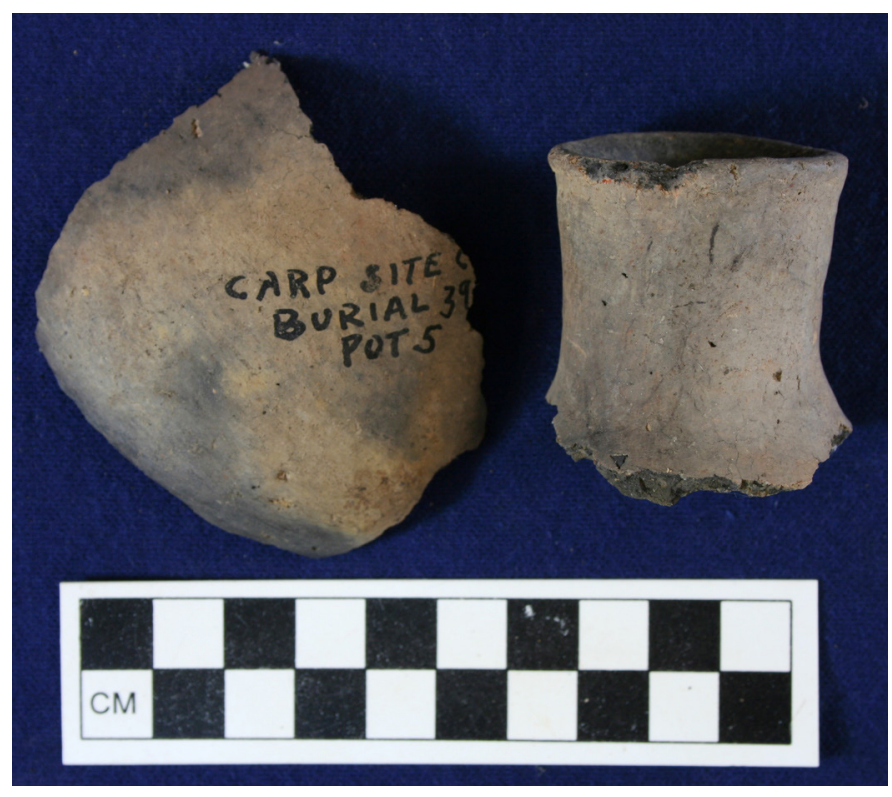

Figure 21. Plain bottle from Burial 39 (Pot 5) at the Tuck Carpenter site.

BASE DIAMETER (IN CM) AND SHAPE OF BASE: 4.9; circular and flat

ESTIMATED VOLUME (IN LITERS): N/A

DECORATION (INCLUDING MOTIF AND ELEMENTS WHEN APPARENT): Plain (Figure 21)

PIGMENT USE AND LOCATION ON VESSEL: none

TYPE AND VARIETY (IF KNOWN): Unidentified plain ware 
SITE NAME OR SITE NUMBER: Tuck Carpenter

VESSEL NO.: NAGPRA 2012.1.246

VESSEL FORM: Jar

NON-PLASTICS AND PASTE: grog

RIM AND LIP FORM: Everted rim and rounded, exterior folded lip

CORE COLOR: G (fired in a reducing environment and cooled in the open air)

INTERIOR SURFACE COLOR: yellowishbrown; fire clouds on the rim and body; thick organic residue on the rim and body

EXTERIOR SURFACE COLOR: dark grayishbrown; fire clouds on the rim and body; organic residue on the rim and body

WALL THICKNESS (IN MM): rim, 7.4 mm; body, $7.4 \mathrm{~mm}$

INTERIOR SURFACE TREATMENT: smoothed

EXTERIOR SURFACE TREATMENT: smoothed

HEIGHT (IN CM): 32.5

ORIFICE DIAMETER (IN CM): 30.0

DIAMETER AT BOTTOM OF RIM OR NECK (IN CM): 29.2

BASE DIAMETER (IN CM) AND SHAPE OF BASE: N/A

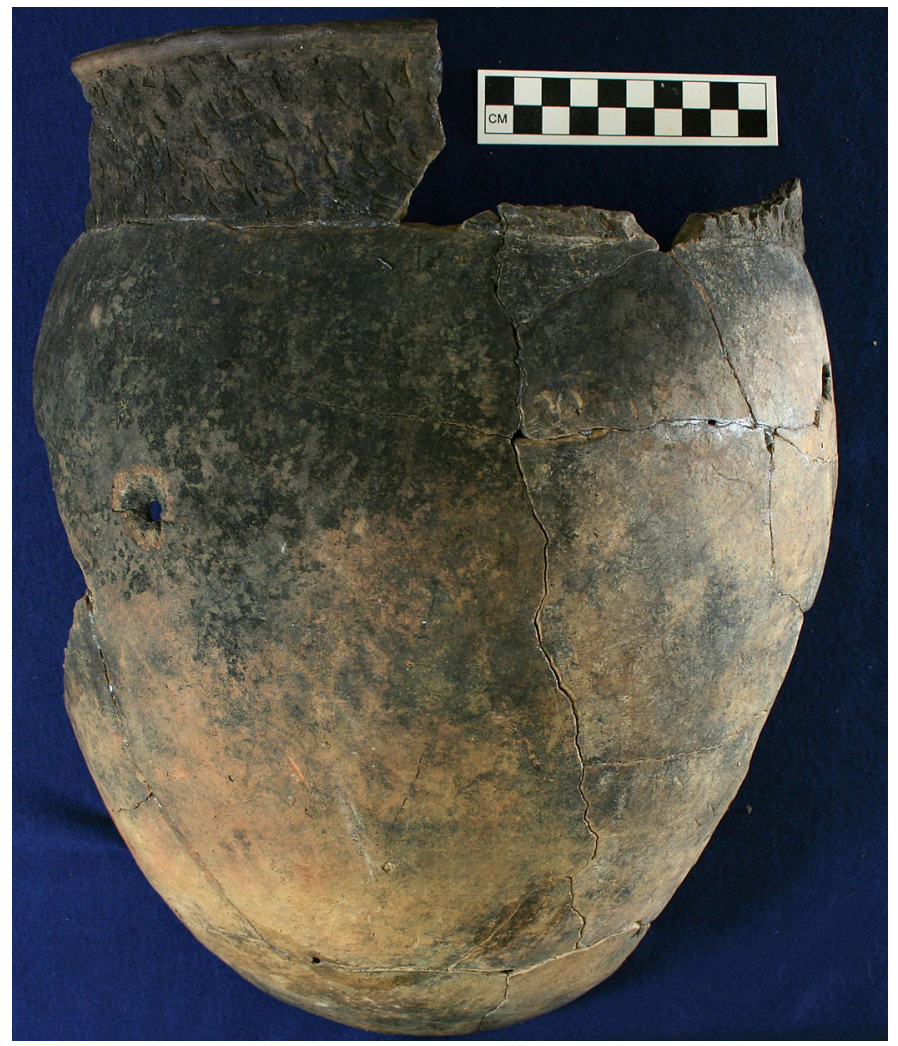

Figure 22. Mockingbird Punctated jar from the Tuck Carpenter site.

ESTIMATED VOLUME (IN LITERS): 12.7

DECORATION (INCLUDING MOTIF AND ELEMENTS WHEN APPARENT): The rim is decorated with five irregular rows of tool punctates (Figure 22).

PIGMENT USE AND LOCATION ON VESSEL: none

TYPE AND VARIETY (IF KNOWN): Mockingbird Punctated 
SITE NAME OR SITE NUMBER: Tuck Carpenter

VESSEL NO.: NAGPRA 2012.1.543

VESSEL FORM: Carinated bowl

NON-PLASTICS AND PASTE: grog

RIM AND LIP FORM: Direct rim and rounded, exterior folded lip

CORE COLOR: F (fired in a reducing environment and cooled in the open air)

INTERIOR SURFACE COLOR: dark yellowishbrown

EXTERIOR SURFACE COLOR: yellowishbrown; fire clouds on the rim and body

WALL THICKNESS (IN MM): rim, 4.9 mm; body, $5.3 \mathrm{~mm}$

INTERIOR SURFACE TREATMENT: burnished

EXTERIOR SURFACE TREATMENT: burnished

HEIGHT (IN CM): N/A; rim height is $6.6 \mathrm{~cm}$

ORIFICE DIAMETER (IN CM): 25.0

DIAMETER AT BOTTOM OF RIM OR NECK

(IN CM): 24.8

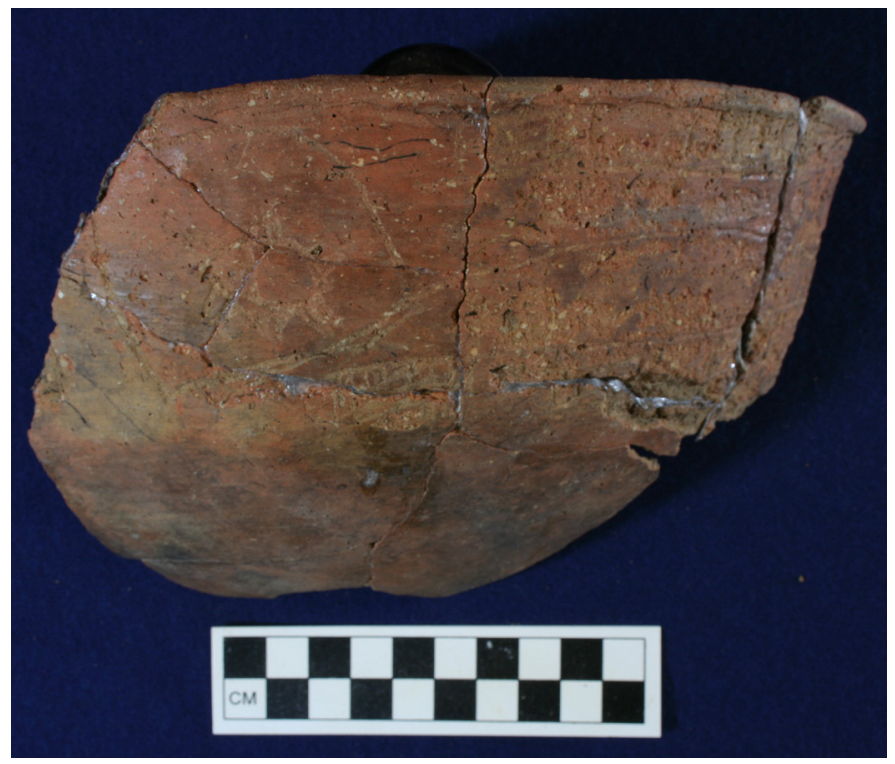

Figure 23. Ripley Engraved, var. Galt carinated bowl from the Tuck Carpenter site.

BASE DIAMETER (IN CM) AND SHAPE OF BASE: N/A

ESTIMATED VOLUME (IN LITERS): N/A

DECORATION (INCLUDING MOTIF AND ELEMENTS WHEN APPARENT): The rim has an engraved scroll and circle motif repeated four times around the vessel. The central circle element has a small inner circle with five excised pendant triangles around its circumference. The upper and lower scroll fill zones have excised triangles and columns at either end of the zones (Figure 23).

PIGMENT USE AND LOCATION ON VESSEL: white pigment in the engraved lines

TYPE AND VARIETY (IF KNOWN): Ripley Engraved, var. Galt 


\section{Harold Williams Site (41CP10)}

The Harold Williams site, also referred to as the Albert Hilton Farm in the mid-1940s when the site was initially found, was first brought to notice when a large flood (in 1943?) washed out a number of Caddo burials and ceramic vessels on a low terrace of Dry Creek, a tributary to Big Cypress Creek (Turner 1997; Turner and Smith 2003). Mr. Hilton sold the vessels he collected to several individuals, including Robert L. Turner, Jr.

In 1959, Ralph Nicholas, Ed German, and Turner excavated 19 extended Caddo burials from a Titus phase cemetery in one area of the Harold Williams site (Turner 1997; Turner and Smith 2003). Funerary offerings in these burials includes 55 ceramic vessels, one ceramic elbow pipe, a single pulley-shaped ceramic ear spool, three Bassett arrow points, 14 Talco points, an abrading stone, and three ground stone celts (Turner and Smith 2003:Table 14). Anecdotal information also suggests that more than 80 burials have actually been excavated from the site over the years, and thus that there is a ca. A.D. 1550-early 1600s Titus phase community cemetery at this place (Turner and Smith 2003:39,54).

Archeological investigations in 1967, before and during a Texas Archeological Society Field School held at the site, documented that the Harold Williams site also has Middle Caddo period habitation deposits, including a midden covering a 75 x $60 \mathrm{~m}$ area (ca. 1.1 acres) (Thurmond 1990:146), post holes from an oval structure, extensive amounts of daub, pit features, and three burials (with nine vessels) in Area A at the eastern end of the site. Among the funerary offerings from these burials is a Nacogdoches Engraved bottle with an engraved rattlesnake motif (Turner and Smith 2003:Figure 12b, d-e). 
SITE NAME OR SITE NUMBER: Harold Williams

VESSEL NO.: Burial J, Pot 3

VESSEL FORM: Compound bowl

NON-PLASTICS AND PASTE: grog

RIM AND LIP FORM: Everted rim and rounded, exterior folded lip

CORE COLOR: F (fired in a reducing environment and cooled in the open air)

INTERIOR SURFACE COLOR: dark yellowish-brown; fire clouds on the rim and body

EXTERIOR SURFACE COLOR: yellowishbrown; fire clouds on the rim and body; organic residue on the rim

WALL THICKNESS (IN MM): rim, upper panel, $7.5 \mathrm{~mm}$; body, $6.0 \mathrm{~mm}$; base, $13.0 \mathrm{~mm}$

INTERIOR SURFACE TREATMENT: smoothed EXTERIOR SURFACE TREATMENT: smoothed HEIGHT (IN CM): N/A; rim upper panel height, $5.9 \mathrm{~cm}$

ORIFICE DIAMETER (IN CM): 28.0

DIAMETER AT BOTTOM OF RIM OR NECK (IN CM): 27.4

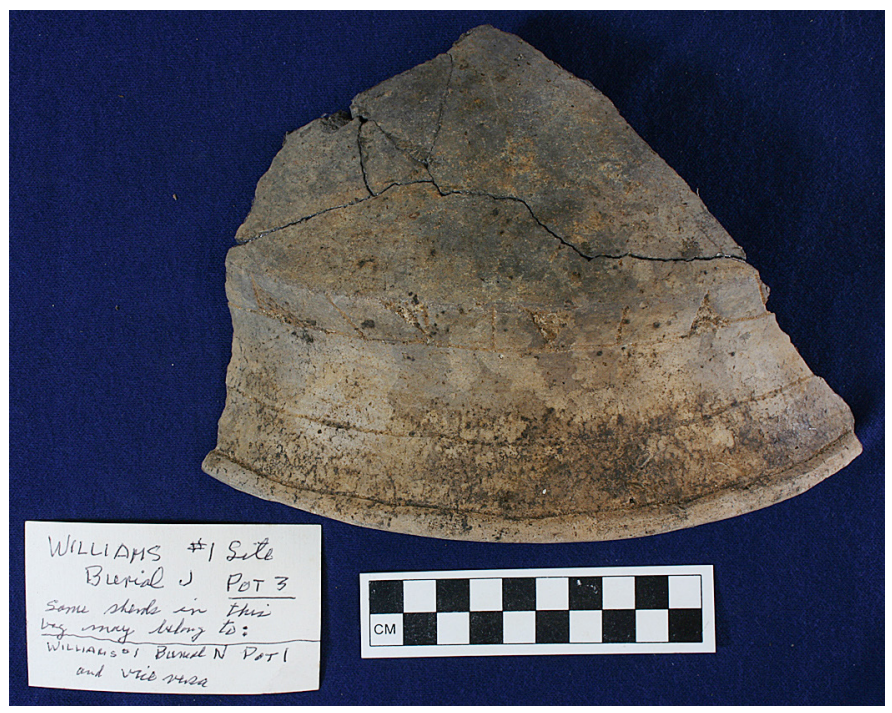

Figure 24. Turner Engraved, var. Turner compound bowl from Burial J (Pot 3) at the Harold Williams site.

BASE DIAMETER (IN CM) AND SHAPE OF BASE: N/A; circular and flat

ESTIMATED VOLUME (IN LITERS): N/A

DECORATION (INCLUDING MOTIF AND ELEMENTS WHEN APPARENT): There are two widelyspaced horizontal engraved lines on the upper rim panel. The lower rim panel has an alternating series of large excised pendant triangles, vertical engraved lines between the triangles, as well as diagonal engraved lines between the excised triangles (Figure 24).

PIGMENT USE AND LOCATION ON VESSEL: none

TYPE AND VARIETY (IF KNOWN): Turner Engraved, var. Turner 
SITE NAME OR SITE NUMBER:

VESSEL NO.: Burial J, Pot 5

VESSEL FORM: Compound bowl

NON-PLASTICS AND PASTE: grog

RIM AND LIP FORM: Everted rim and rounded, exterior folded lip

CORE COLOR: C (incompletely oxidized during firing)

INTERIOR SURFACE COLOR: yellowish-brown

EXTERIOR SURFACE COLOR: yellowish-brown

WALL THICKNESS (IN MM): rim, $8.2 \mathrm{~mm}$; body, $7.6 \mathrm{~mm}$

INTERIOR SURFACE TREATMENT: smoothed

EXTERIOR SURFACE TREATMENT: burnished

HEIGHT (IN CM): N/A; upper and lower rim panel height is $17.7 \mathrm{~cm}$

ORIFICE DIAMETER (IN CM): 34.0

DIAMETER AT BOTTOM OF RIM OR NECK (IN CM): 32.6

BASE DIAMETER (IN CM) AND SHAPE OF BASE: N/A

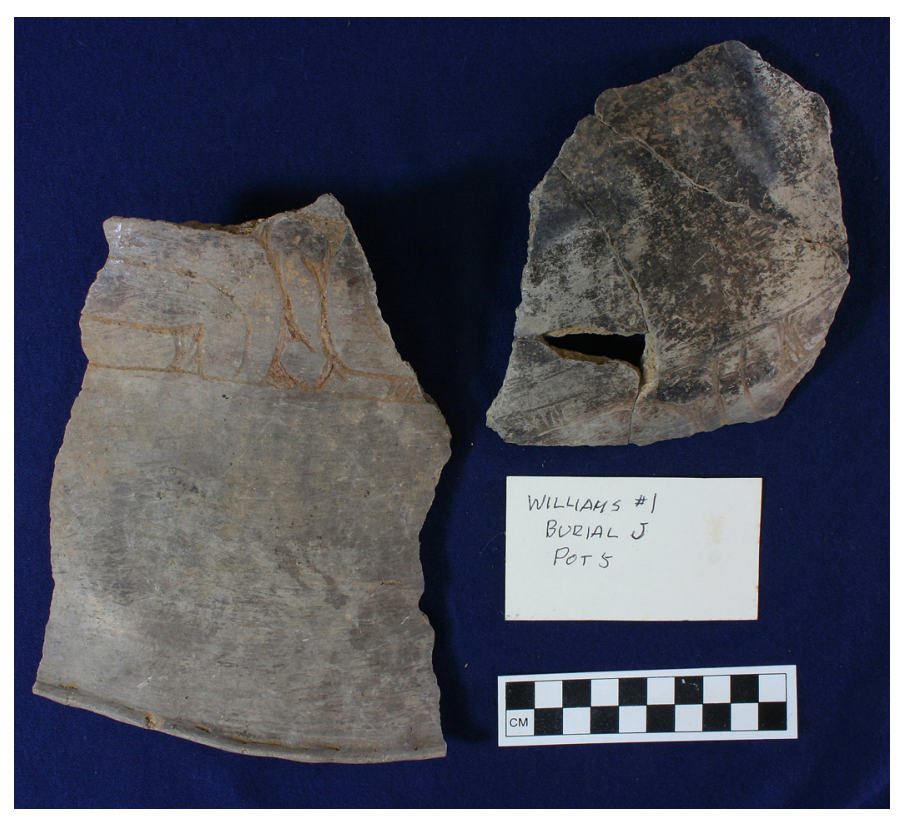

\section{ESTIMATED VOLUME (IN LITERS): N/A}

Figure 25. Ripley Engraved, var. Gandy compound bowl from Burial J (Pot 5) at the Harold Williams site.

DECORATION (INCLUDING MOTIF AND ELEMENTS WHEN APPARENT): The upper rim panel is plain, but the lower rim panel has an engraved scroll motif repeated four times around the vessel (Figure 25). The upper and lower scroll fill zones have excised brackets and columns and negative ovals; the lager of the negative ovals has a vertical engraved line through its center. The scrolls are divided by four negative S-elements that are within excised brackets.

PIGMENT USE AND LOCATION ON VESSEL: none

TYPE AND VARIETY (IF KNOWN): Ripley Engraved, var. Gandy 
SITE NAME OR SITE NUMBER: Harold Williams

VESSEL NO.: Burial K, Pot 1

VESSEL FORM: Jar

NON-PLASTICS AND PASTE: grog and bone

RIM AND LIP FORM: Direct rim and rounded lip

CORE COLOR: G (fired in a reducing environment and cooled in the open air)

INTERIOR SURFACE COLOR: dark grayish-brown

EXTERIOR SURFACE COLOR: dark yellowish-brown; fire clouds on the rim and body

WALL THICKNESS (IN MM): rim, 8.4 mm; body,

$8.7 \mathrm{~mm}$; base, $11.5 \mathrm{~mm}$

INTERIOR SURFACE TREATMENT: smoothed

EXTERIOR SURFACE TREATMENT: none

HEIGHT (IN CM): N/A

ORIFICE DIAMETER (IN CM): 25.0

DIAMETER AT BOTTOM OF RIM OR NECK (IN CM): 25.1

BASE DIAMETER (IN CM) AND SHAPE OF BASE: N/A; circular and flat

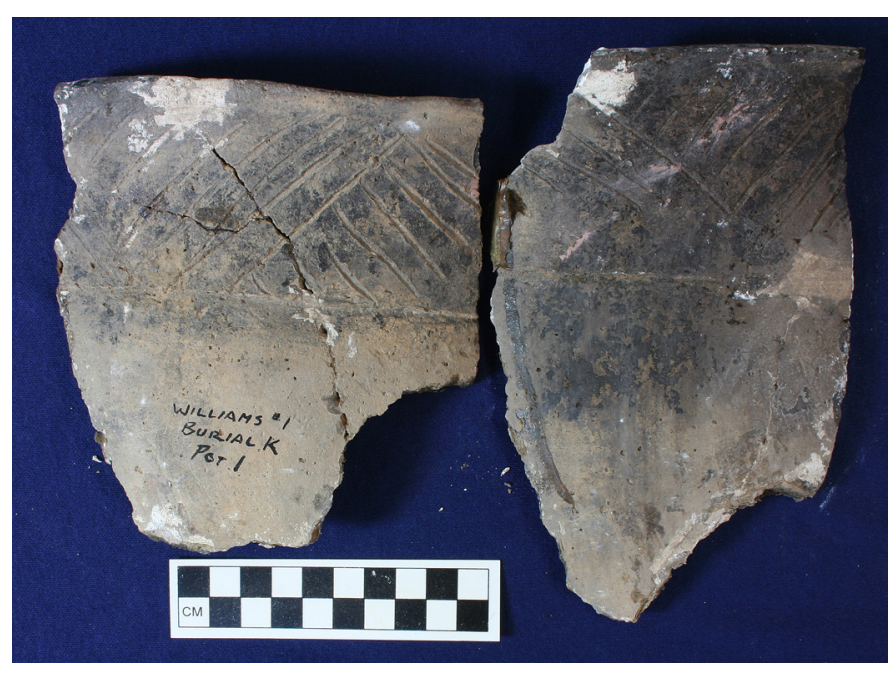

Figure 26. Maydelle Incised jar from Burial K (Pot 1) at the Harold Williams site.

ESTIMATED VOLUME (IN LITERS): N/A

DECORATION (INCLUDING MOTIF AND ELEMENTS WHEN APPARENT): The rim has a series of diagonal opposed incised chevrons that are repeated around the vessel (Figure 26).

PIGMENT USE AND LOCATION ON VESSEL: none

TYPE AND VARIETY (IF KNOWN): Maydelle Incised 
SITE NAME OR SITE NUMBER: Harold Williams

VESSEL NO.: Burial K, Pot 8

VESSEL FORM: Carinated bowl

NON-PLASTICS AND PASTE: grog

RIM AND LIP FORM: Direct rim and a rounded, exterior folded lip

CORE COLOR: F (fired in a reducing environment and cooled in the open air)

INTERIOR SURFACE COLOR: yellowish-brown; fire clouds on the rim, body, and base

EXTERIOR SURFACE COLOR: yellowishbrown; fire clouds on the rim, body, and base

WALL THICKNESS (IN MM): rim, $7.5 \mathrm{~mm}$; body, $7.5 \mathrm{~mm}$; base, $7.2 \mathrm{~mm}$

INTERIOR SURFACE TREATMENT: smoothed

EXTERIOR SURFACE TREATMENT:

smoothed

HEIGHT (IN CM): 17.5

ORIFICE DIAMETER (IN CM): 30.0

DIAMETER AT BOTTOM OF RIM OR NECK (IN CM): 29.8

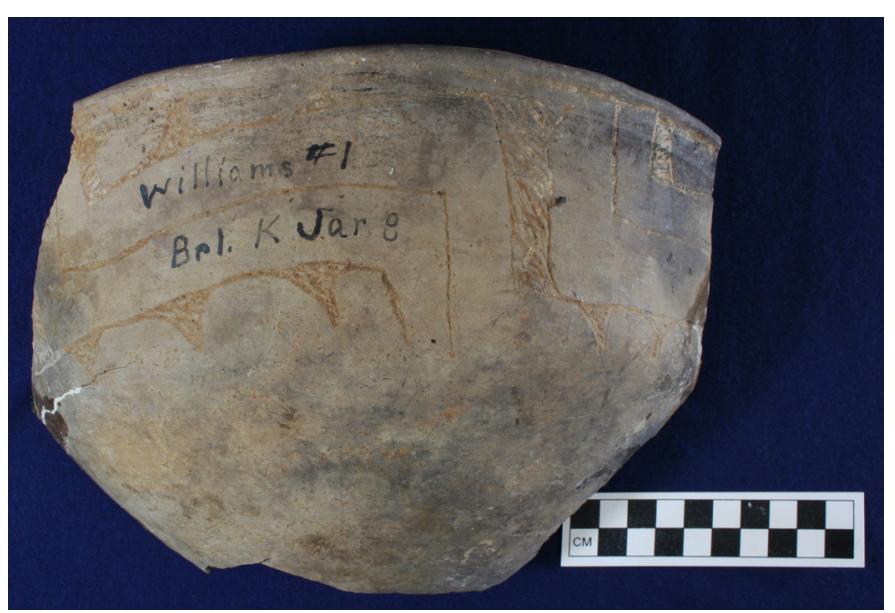

Figure 27. Ripley Engraved, var. unspecified carinated bowl from Burial K (Pot 8) at the Harold Williams site.

BASE DIAMETER (IN CM) AND SHAPE OF BASE: 8.0; circular and flat

ESTIMATED VOLUME (IN LITERS): 4.7

DECORATION (INCLUDING MOTIF AND ELEMENTS WHEN APPARENT): The rim panel has an engraved scroll motif repeated four times around the vessel. The scrolls are divided by column and bracketshaped areas filled with diagonal hatched lines. Above and below the scroll lines are fill zones with hatched pendant triangles and hatched or cross-hatched columns (Figure 27).

PIGMENT USE AND LOCATION ON VESSEL: white pigment in the engraved lines

TYPE AND VARIETY (IF KNOWN): Ripley Engraved, var. unspecified 
SITE NAME OR SITE NUMBER: Harold Williams

VESSEL NO.: Burial N, Pot 1

VESSEL FORM: Carinated bowl

NON-PLASTICS AND PASTE: grog

RIM AND LIP FORM: Direct rim and a rounded, exterior folded lip

CORE COLOR: F (fired in a reducing environment and cooled in the open air)

INTERIOR SURFACE COLOR: dark yellowish-brown; fire clouds on the rim and body

EXTERIOR SURFACE COLOR: dark yellowish-brown; fire clouds on the rim and body

WALL THICKNESS (IN MM): rim, $6.2 \mathrm{~mm}$; body, $6.4 \mathrm{~mm}$

INTERIOR SURFACE TREATMENT: smoothed

EXTERIOR SURFACE TREATMENT:

burnished

HEIGHT (IN CM): N/A; rim height is $4.5 \mathrm{~cm}$

ORIFICE DIAMETER (IN CM): 29.0

DIAMETER AT BOTTOM OF RIM OR NECK (IN CM): 28.7

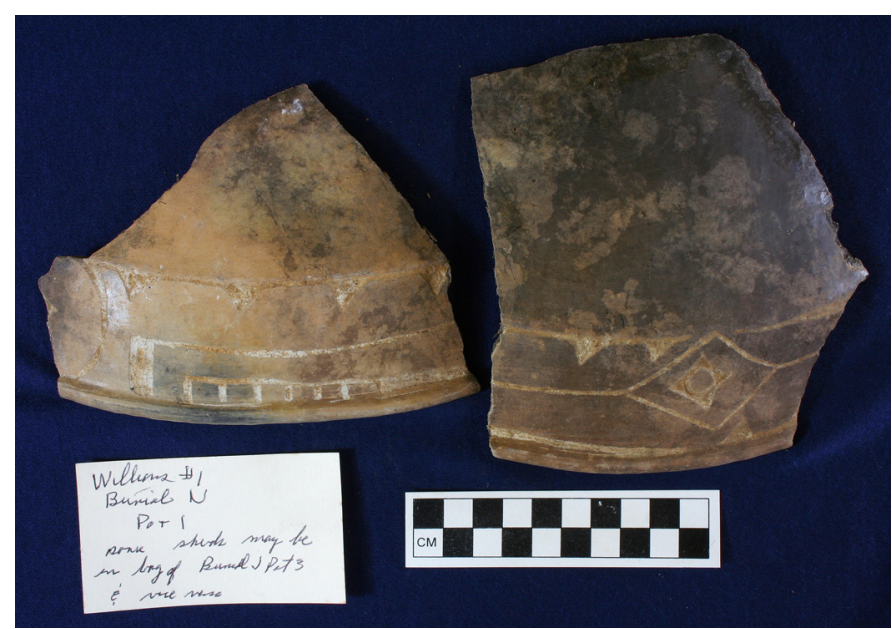

Figure 28. Ripley Engraved, var. McKinney carinated bowl from Burial N (Pot 1) at the Harold Williams site.

BASE DIAMETER (IN CM) AND SHAPE OF BASE: N/A

\section{ESTIMATED VOLUME (IN LITERS): N/A}

DECORATION (INCLUDING MOTIF AND ELEMENTS WHEN APPARENT): The rim panel has an engraved horizontal scroll with two alternating circle and diamond central elements; the scrolls end in excised vertical columns. The central circles have a central inner diamond element with a small negative circle formed by excising, while the central diamonds also have central inner diamond elements with a small negative circle formed by excising (Figure 28). Above and below the horizontal scroll lines are sets of excised pendant triangles or zones with an excised triangle and a series of vertical engraved lines. There is also a single horizontal engraved line on the vessel interior at the carination.

PIGMENT USE AND LOCATION ON VESSEL: white pigment in engraved lines TYPE AND VARIETY (IF KNOWN): cf. Ripley Engraved, var. McKinney 
SITE NAME OR SITE NUMBER: Harold Williams

VESSEL NO.: Burial N, Pot 4

VESSEL FORM: Compound bowl

NON-PLASTICS AND PASTE: grog

RIM AND LIP FORM: Direct rim and rounded, exterior folded lip

CORE COLOR: F (fired in a reducing environment and cooled in the open air)

INTERIOR SURFACE COLOR: yellowish-brown; fire clouds on the body and base

EXTERIOR SURFACE COLOR: yellowish-brown; fire clouds on the body

WALL THICKNESS (IN MM): rim, $7.7 \mathrm{~mm}$;

body, $8.4 \mathrm{~mm}$; base, $10.3 \mathrm{~mm}$

INTERIOR SURFACE TREATMENT: smoothed

EXTERIOR SURFACE TREATMENT: burnished

HEIGHT (IN CM): N/A; upper and lower rim panel height, $11.9 \mathrm{~cm}$

ORIFICE DIAMETER (IN CM): 31.0

DIAMETER AT BOTTOM OF RIM OR NECK

(IN CM): 33.5

BASE DIAMETER (IN CM) AND SHAPE OF

BASE: N/A; circular and flat

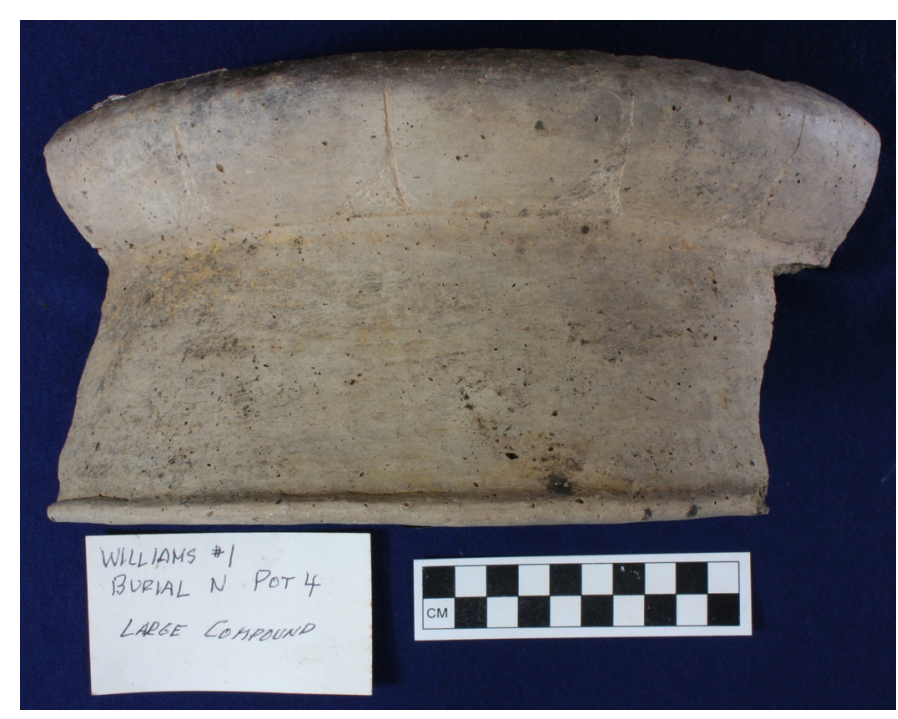

Figure 29. Turner Engraved, var. Turner compound bowl from Burial N (Pot 4) at the Harold Williams site.

\section{ESTIMATED VOLUME (IN LITERS): N/A}

DECORATION (INCLUDING MOTIF AND ELEMENTS WHEN APPARENT): The upper rim plain is plain, but the lower rim panel has an unknown series of large cross-hatched pendant triangles, with a long engraved line extending downward from their apexes (Figure 29).

PIGMENT USE AND LOCATION ON VESSEL: none

TYPE AND VARIETY (IF KNOWN): Turner Engraved, var. Turner 
SITE NAME OR SITE NUMBER: Harold Williams

VESSEL NO.: Burial N, Pot 5

VESSEL FORM: Compound bowl

NON-PLASTICS AND PASTE: grog

RIM AND LIP FORM: Everted rim and rounded, exterior folded lip

CORE COLOR: $\mathrm{G}$ (fired in a reducing environment and cooled in the open air)

INTERIOR SURFACE COLOR: dark yellowish-brown; fire clouds on the rim, body, and base

EXTERIOR SURFACE COLOR: grayish-brown; fire clouds on the rim, body, and base

WALL THICKNESS (IN MM): rim, $7.3 \mathrm{~mm}$;

body, $7.9 \mathrm{~mm}$; base, $10.2 \mathrm{~mm}$

INTERIOR SURFACE TREATMENT: smoothed

EXTERIOR SURFACE TREATMENT: smoothed

HEIGHT (IN CM): 26.0

ORIFICE DIAMETER (IN CM): 44.0

DIAMETER AT BOTTOM OF RIM OR NECK

(IN CM): 43.8

BASE DIAMETER (IN CM) AND SHAPE OF

BASE: 9.0; circular and flat

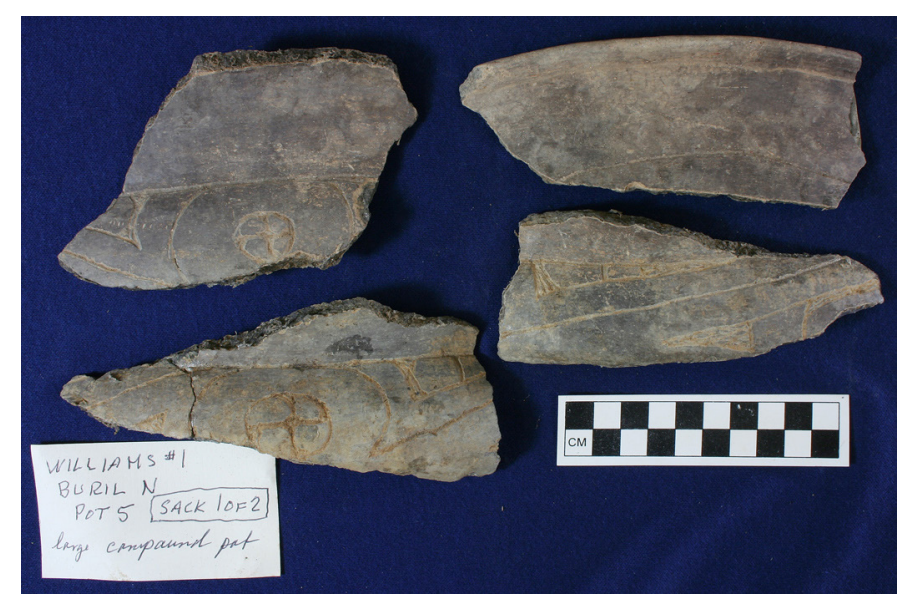

Figure 30. Ripley Engraved, var. Cash compound bowl from Burial N (Pot 5) at the Harold Williams site.

\section{ESTIMATED VOLUME (IN LITERS): 9.2}

DECORATION (INCLUDING MOTIF AND ELEMENTS WHEN APPARENT): The upper rim panel has two widely-spaced horizontal engraved lines. The lower rim panel has an engraved circle and nested triangle motif that is repeated four times around the vessel (Figure 30). The central circle elements have crossed lines with small excised triangles at their ends. The nested triangles have a small inner oval with cross-hatched triangles in their corners; a central oval; and a central excised dot. Above or below the nested triangles are two side-by-side triangular zones filled with excised brackets, triangles, and vertical excised lines.

PIGMENT USE AND LOCATION ON VESSEL: none

TYPE AND VARIETY (IF KNOWN): Ripley Engraved, var. Cash 


\section{B. J. Horton Site (41CP20)}

The B. J. Horton site (41CP20) is on an upland ridge overlooking the Big Cypress Creek floodplain (see Perttula et al. 2010:Figure 6); Walkers Creek lies a short distance to the south (Hunt et al. 1996:Figure 1). The site is primarily a Titus phase cemetery with at least 19 excavated burials (Turner 1978:Figure 33; Perttula 2014).

Ralph Nicholas, Ed German, and Robert L. Turner, Jr. excavated 15 burials at the site in September and October 1958, and several others were known to have been excavated by Alan Young in the late 1960s (Hunt et al. 1996:15). Available notes and records from several of the burials (Burials 1-5, 8-12, and 15) compiled by Turner have been reproduced by Hunt et al. (1996:Appendix F). These indicate that the following funerary offerings were placed with the burials: 83 ceramic vessels, one ceramic pipe, two Perdiz points, one Maud point, 23 Bassett points, two Talco point, nine unidentified points, and two ground stone celts. 
SITE NAME OR SITE NUMBER: B. J. Horton

VESSEL NO.: Burial 2, Pot 2

VESSEL FORM: Carinated bowl

NON-PLASTICS AND PASTE: grog

RIM AND LIP FORM: Direct rim and rounded lip

CORE COLOR: F (fired in a reducing environment and cooled in the open air)

INTERIOR SURFACE COLOR: light brown; fire clouds on the rim, body, and base

EXTERIOR SURFACE COLOR: light brown; fire clouds on the base

WALL THICKNESS (IN MM): rim, 8.7 mm; body, $9.2 \mathrm{~mm}$; base, $11.6 \mathrm{~mm}$

INTERIOR SURFACE TREATMENT: smoothed

EXTERIOR SURFACE TREATMENT:

smoothed

HEIGHT (IN CM): 14.5

ORIFICE DIAMETER (IN CM): 23.0

DIAMETER AT BOTTOM OF RIM OR NECK (IN CM): 23.0

BASE DIAMETER (IN CM) AND SHAPE OF BASE: 8.2 ; circular and flat

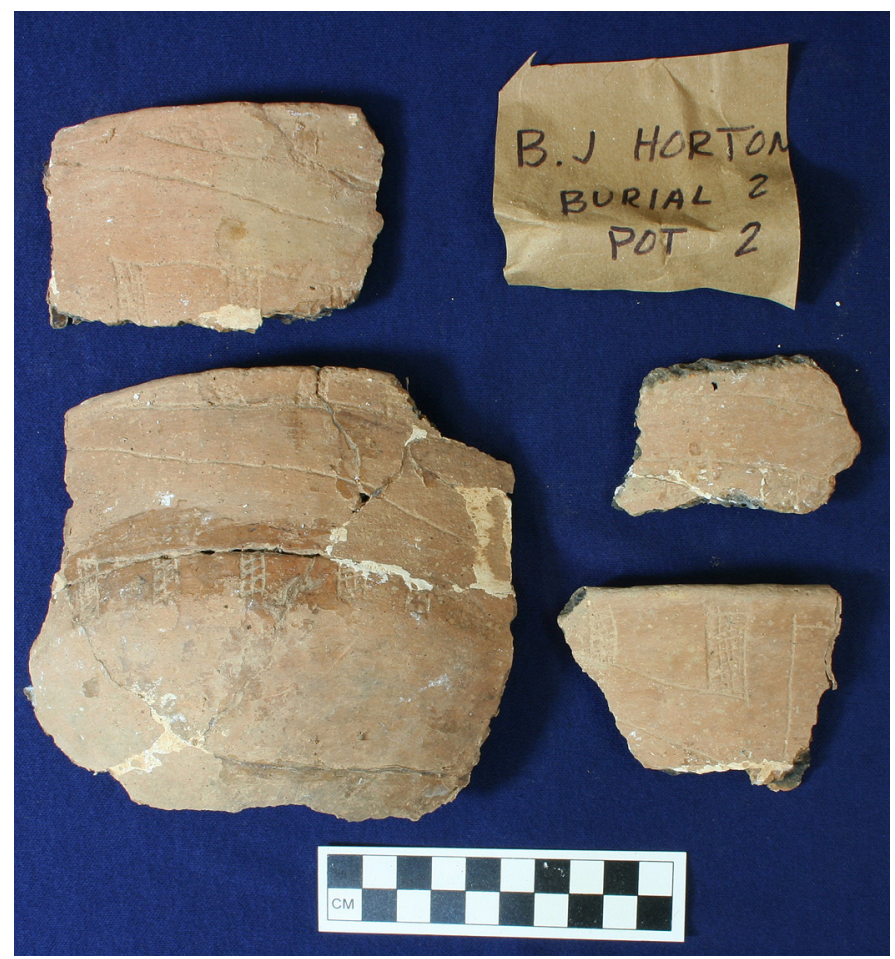

Figure 31. Ripley Engraved, var. Carpenter carinated bowl from Burial 2 (Pot 2) at the B. J. Horton site.

ESTIMATED VOLUME (IN LITERS): 3.0

DECORATION (INCLUDING MOTIF AND ELEMENTS WHEN APPARENT): The rim panel has an engraved continuous scroll motif repeated four times around the vessel. The upper and lower scroll fill zones have a series of narrow cross-hatched column and bracket elements (Figure 31).

PIGMENT USE AND LOCATION ON VESSEL: none

TYPE AND VARIETY (IF KNOWN): Ripley Engraved, var. Carpenter 
SITE NAME OR SITE NUMBER: B. J. Horton

VESSEL NO.: Burial 2, Pot 8

VESSEL FORM: Jar

NON-PLASTICS AND PASTE: grog

RIM AND LIP FORM: N/A

CORE COLOR: $\mathrm{G}$ (fired in a reducing environment and cooled in the open air)

INTERIOR SURFACE COLOR: brown; fire clouds on the body and base

EXTERIOR SURFACE COLOR: yellowishbrown; fire clouds on the body and base

WALL THICKNESS (IN MM): body, $7.6 \mathrm{~mm}$; base, $9.7 \mathrm{~mm}$

INTERIOR SURFACE TREATMENT: smoothed

EXTERIOR SURFACE TREATMENT: none

HEIGHT (IN CM): N/A

ORIFICE DIAMETER (IN CM): N/A

DIAMETER AT BOTTOM OF RIM OR NECK (IN CM): N/A

BASE DIAMETER (IN CM) AND SHAPE OF BASE: 8.0; circular and flat

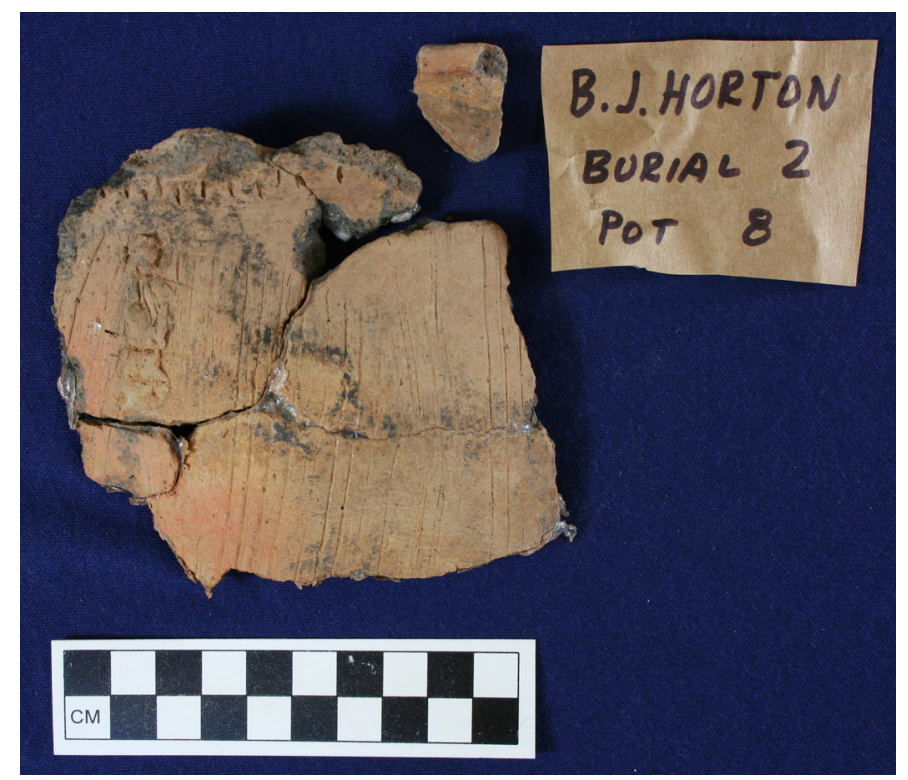

Figure 32. Probable Pease Brushed-Incised jar from Burial 2 (Pot 8) at the B. J. Horton site.

\section{ESTIMATED VOLUME (IN LITERS): N/A}

DECORATION (INCLUDING MOTIF AND ELEMENTS WHEN APPARENT): The vessel has a row of tool punctates at the rim-body juncture. The vessel body has vertical appliqued fillets that have created panels filled with vertical brushing marks (Figure 32). The appliqued fillets and brushing marks extend to within $3.5 \mathrm{~cm}$ of the vessel base.

PIGMENT USE AND LOCATION ON VESSEL: none

TYPE AND VARIETY (IF KNOWN): Unidentified utility ware, probably Pease Brushed-Incised 
SITE NAME OR SITE NUMBER: B. J. Horton

VESSEL NO.: Burial 4, Pot 1

VESSEL FORM: Jar

NON-PLASTICS AND PASTE: grog

RIM AND LIP FORM: N/A

CORE COLOR: F (fired in a reducing environment and cooled in the open air)

INTERIOR SURFACE COLOR: yellowish-brown; fire clouds on the body and base

EXTERIOR SURFACE COLOR: yellowishbrown; fire clouds on the body and base

WALL THICKNESS (IN MM): body, $6.8 \mathrm{~mm}$; base, $15.7 \mathrm{~mm}$

INTERIOR SURFACE TREATMENT: smoothed

EXTERIOR SURFACE TREATMENT: smoothed

HEIGHT (IN CM): N/A

ORIFICE DIAMETER (IN CM): N/A

DIAMETER AT BOTTOM OF RIM OR NECK (IN CM): N/A

BASE DIAMETER (IN CM) AND SHAPE OF BASE: N/A

ESTIMATED VOLUME (IN LITERS): N/A

DECORATION (INCLUDING MOTIF AND

ELEMENTS WHEN APPARENT): Plain

(Figure 33)

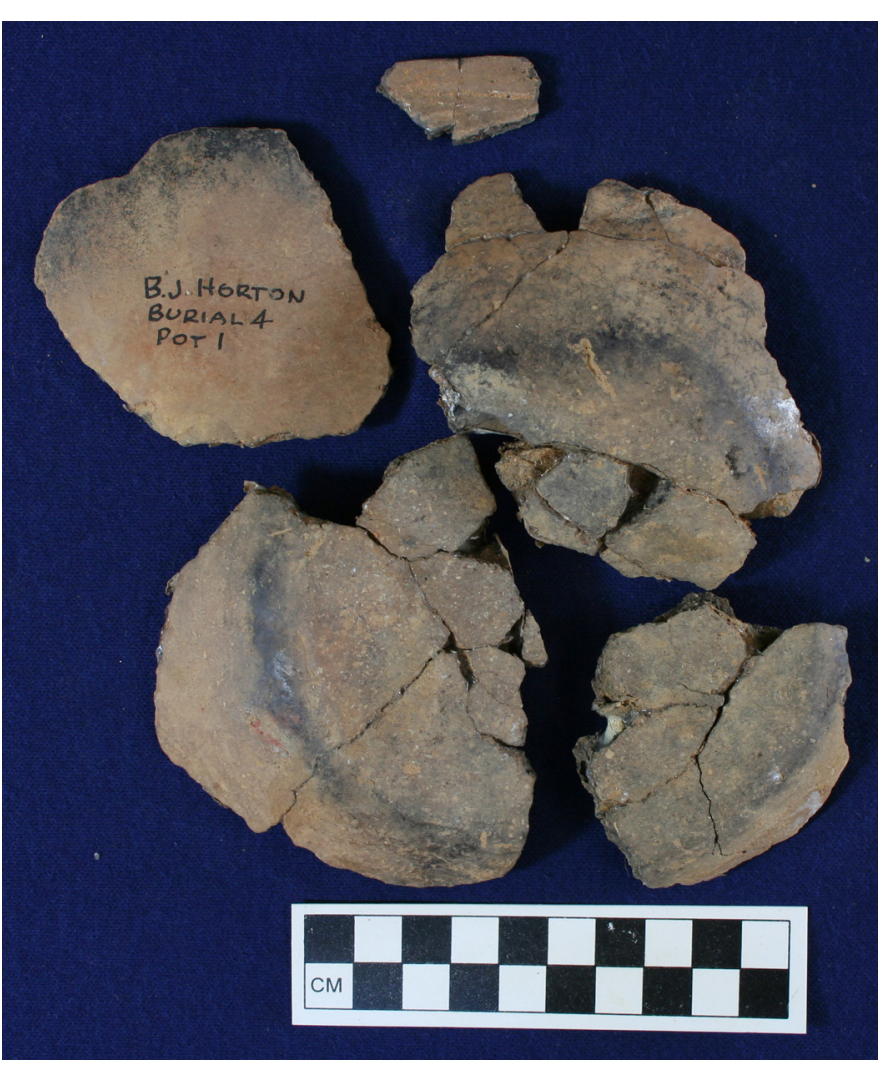

Figure 33. Plain jar from Burial 4 (Pot 1) at the B. J. Horton site.

PIGMENT USE AND LOCATION ON VESSEL: none

TYPE AND VARIETY (IF KNOWN): Unidentified plain ware 
SITE NAME OR SITE NUMBER: B. J. Horton

VESSEL NO.: Burial 4, Pot 2

VESSEL FORM: Compound bowl with rim peaks

NON-PLASTICS AND PASTE: grog

RIM AND LIP FORM: Direct rim and rounded, exterior folded lip

CORE COLOR: F (fired in a reducing environment and cooled in the open air)

INTERIOR SURFACE COLOR: yellowish-brown; fire clouds on the rim and body

EXTERIOR SURFACE COLOR: yellowish-brown; fire clouds on the rim and body

WALL THICKNESS (IN MM): rim, $4.8 \mathrm{~mm}$;

body, $5.5 \mathrm{~mm}$; base, $6.5 \mathrm{~mm}$

INTERIOR SURFACE TREATMENT:

smoothed

EXTERIOR SURFACE TREATMENT:

smoothed

HEIGHT (IN CM): ca. 10.0

ORIFICE DIAMETER (IN CM): 15.0

DIAMETER AT BOTTOM OF RIM OR

NECK (IN CM): 15.4

BASE DIAMETER (IN CM) AND SHAPE

OF BASE: N/A; circular and flat

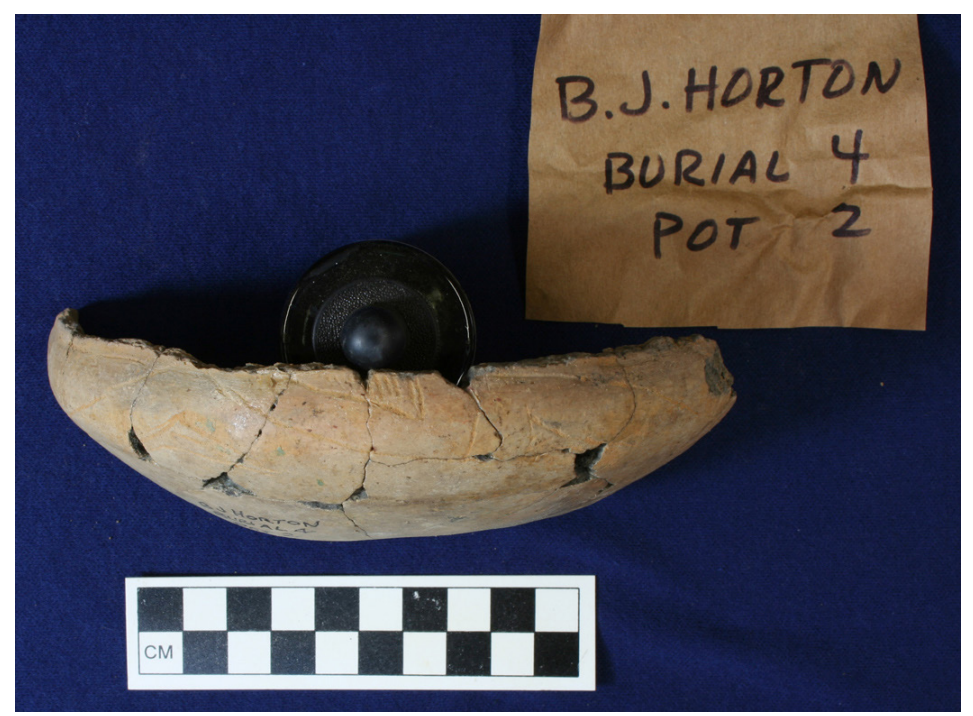

Figure 34. Ripley Engraved, var. unspecified compound bowl from Burial 4 (Pot 2) at the Harold Williams site.

ESTIMATED VOLUME (IN LITERS): 1.2

DECORATION (INCLUDING MOTIF AND ELEMENTS WHEN APPARENT): The upper rim panel has an engraved scroll motif with open pendant triangles and a hatched scroll fill zone. The lower rim panel has an engraved nested triangle motif with a small central hatched triangle within it, as well as hatched upper and lower triangle dividers (Figure 34).

PIGMENT USE AND LOCATION ON VESSEL: none

TYPE AND VARIETY (IF KNOWN): Ripley Engraved, var. unspecified 
SITE NAME OR SITE NUMBER: B. J. Horton

VESSEL NO.: Burial 4, Pot 7

VESSEL FORM: Carinated bowl

NON-PLASTICS AND PASTE: grog

RIM AND LIP FORM: Inverted rim and a rounded lip

CORE COLOR: $\mathrm{F}$ (fired in a reducing environment and cooled in the open air)

INTERIOR SURFACE COLOR: light brown; fire clouds on the base

EXTERIOR SURFACE COLOR: light brown; fire clouds on the body and base

WALL THICKNESS (IN MM): rim, 4.9 mm; body, $5.5 \mathrm{~mm}$; base, $6.7 \mathrm{~mm}$

INTERIOR SURFACE TREATMENT: smoothed EXTERIOR SURFACE TREATMENT: smoothed

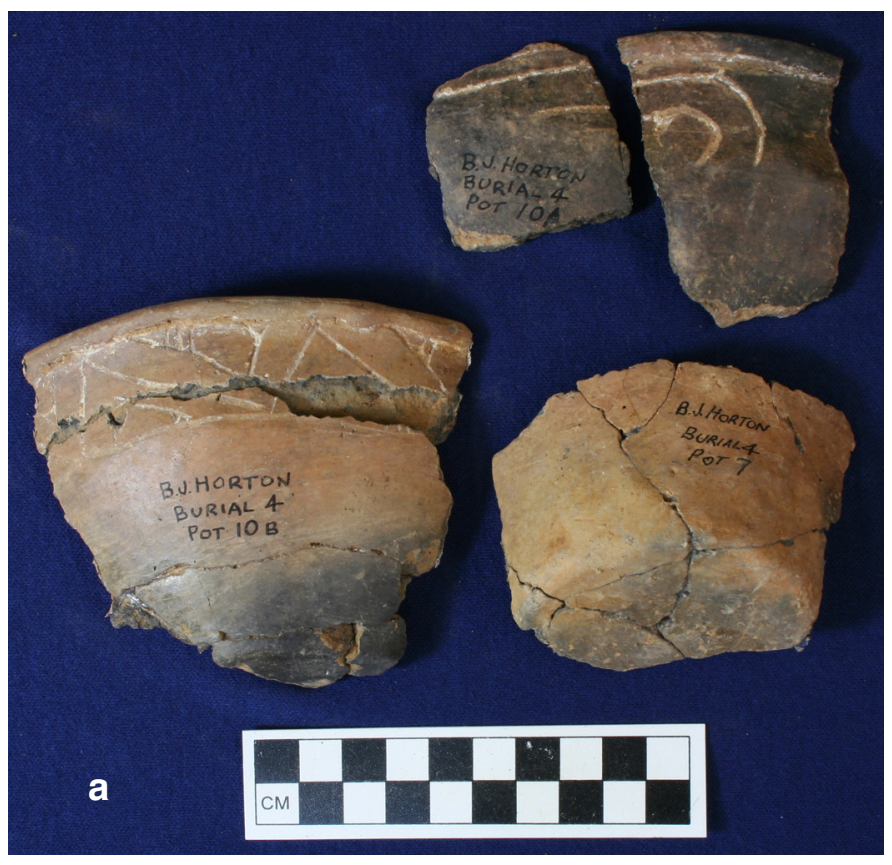

HEIGHT (IN CM): N/A

ORIFICE DIAMETER (IN CM): 9.0

DIAMETER AT BOTTOM OF RIM OR NECK (IN CM): 9.4

BASE DIAMETER (IN CM) AND SHAPE OF BASE: 6.5 ; circular and flat

ESTIMATED VOLUME (IN LITERS): N/A

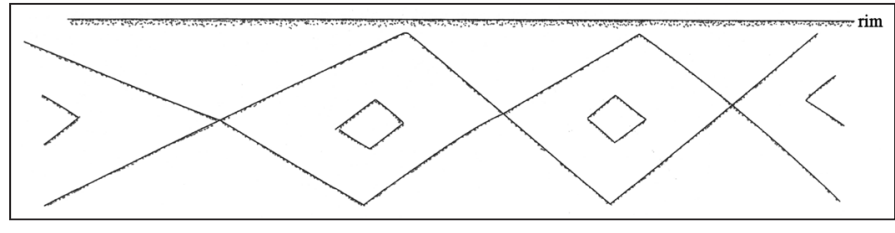

b

Figure 35. Sections of Pots 7, 10A, and 10B from Burial 4 at the Harold Williams site; $b$, decorative element on Burial 4, Pot 7.

DECORATION (INCLUDING MOTIF AND ELEMENTS WHEN APPARENT): The rim panel has a series of engraved interlocking diamonds. Each interlocked diamond has a small central open diamond element within it (Figure 35a-b).

PIGMENT USE AND LOCATION ON VESSEL: white pigment in the engraved lines

TYPE AND VARIETY (IF KNOWN): Ripley Engraved, var. unspecified 
SITE NAME OR SITE NUMBER: B. J. Horton

VESSEL NO.: Burial 4, Pot 10A

VESSEL FORM: Carinated bowl

NON-PLASTICS AND PASTE: grog

RIM AND LIP FORM: Direct rim and a rounded, exterior folded lip

CORE COLOR: B (fired and cooled in a reducing environment)

INTERIOR SURFACE COLOR: dark brown

EXTERIOR SURFACE COLOR: dark brown

WALL THICKNESS (IN MM): rim, $6.5 \mathrm{~mm}$; body, $7.5 \mathrm{~mm}$

INTERIOR SURFACE TREATMENT: burnished

EXTERIOR SURFACE TREATMENT: burnished

HEIGHT (IN CM): N/A

ORIFICE DIAMETER (IN CM): 12.5

DIAMETER AT BOTTOM OF RIM OR NECK (IN CM): 11.5

BASE DIAMETER (IN CM) AND SHAPE OF BASE: N/A

ESTIMATED VOLUME (IN LITERS): N/A

DECORATION (INCLUDING MOTIF AND ELEMENTS WHEN APPARENT): The rim panel has an engraved scroll motif repeated an unknown number of times around the vessel. One scroll line in each motif has small excised pendant triangles (Figure 36; see also Figure 35a). There is also a single horizontal engraved line on the vessel interior at the carination.

PIGMENT USE AND LOCATION ON VESSEL: white pigment in the engraved lines

TYPE AND VARIETY (IF KNOWN): Ripley Engraved, var. unspecified

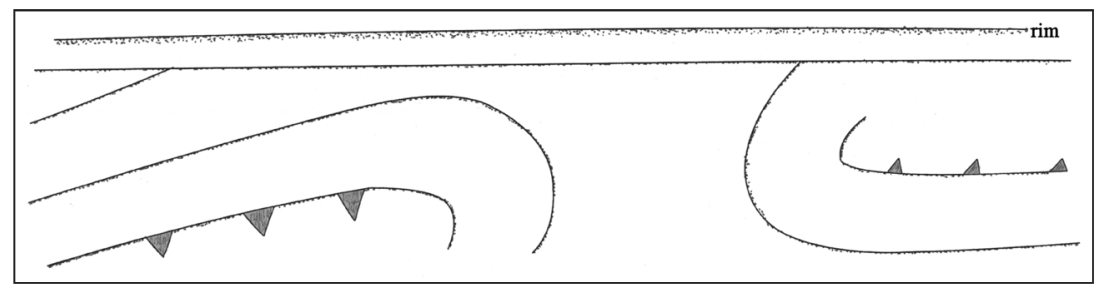

Figure 36. Decorative elements on Burial 4, Pot 10A at the Harold Williams site. 
SITE NAME OR SITE NUMBER: B. J. Horton

VESSEL NO.: Burial 4, Pot 10B

VESSEL FORM: Carinated bowl

NON-PLASTICS AND PASTE: grog

RIM AND LIP FORM: Direct rim and rounded, exterior folded lip

CORE COLOR: $\mathrm{F}$ (fired in a reducing environment and cooled in the open air)

INTERIOR SURFACE COLOR: light brown; fire clouds on the rim, body, and base

EXTERIOR SURFACE COLOR: reddish-brown; fire clouds on the body and base

WALL THICKNESS (IN MM): rim, $5.7 \mathrm{~mm}$; body, $7.0 \mathrm{~mm}$; base, $8.9 \mathrm{~mm}$

INTERIOR SURFACE TREATMENT: smoothed

EXTERIOR SURFACE TREATMENT: burnished

HEIGHT (IN CM): 6.2

ORIFICE DIAMETER (IN CM): 14.5

DIAMETER AT BOTTOM OF RIM OR NECK (IN CM): 14.4

BASE DIAMETER (IN CM) AND SHAPE OF BASE: N/A

ESTIMATED VOLUME (IN LITERS): 0.5

DECORATION (INCLUDING MOTIF AND ELEMENTS WHEN APPARENT): The rim panel has a series of engraved alternated nested triangle elements around the vessel. The nested triangles have a smaller inner triangle with hatched lines at two corners (Figure 37; see also Figure 35a).

PIGMENT USE AND LOCATION ON VESSEL: white pigment in the engraved lines

TYPE AND VARIETY (IF KNOWN): Ripley Engraved, var. Williams

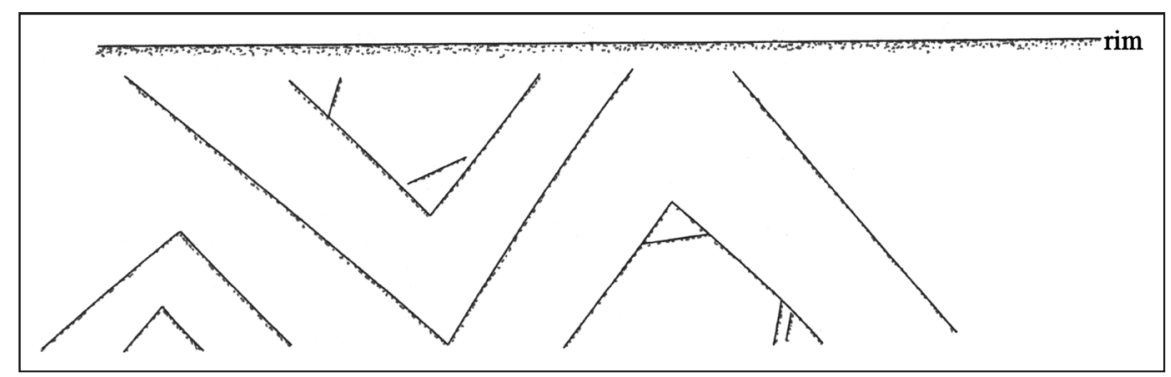

Figure 37. Decorative elements on Burial 4, Pot 10B at the Harold Williams site. 
SITE NAME OR SITE NUMBER: B. J. Horton

VESSEL NO.: Burial 10, Pot 8

VESSEL FORM: Carinated bowl

NON-PLASTICS AND PASTE: grog

RIM AND LIP FORM: Direct rim and rounded, exterior folded lip

CORE COLOR: $\mathrm{F}$ (fired in a reducing environment and cooled in the open air)

INTERIOR SURFACE COLOR: dark yellowishbrown; fire clouds on the body and base

EXTERIOR SURFACE COLOR: yellowishbrown; fire clouds on the rim, body, and base

WALL THICKNESS (IN MM): rim, $6.0 \mathrm{~mm}$; body, $6.2 \mathrm{~mm}$; base, $8.1 \mathrm{~mm}$

INTERIOR SURFACE TREATMENT: smoothed EXTERIOR SURFACE TREATMENT: smoothed

HEIGHT (IN CM): N/A; rim height is $5.9 \mathrm{~cm}$

ORIFICE DIAMETER (IN CM): 29.0

DIAMETER AT BOTTOM OF RIM

OR NECK (IN CM): 28.8
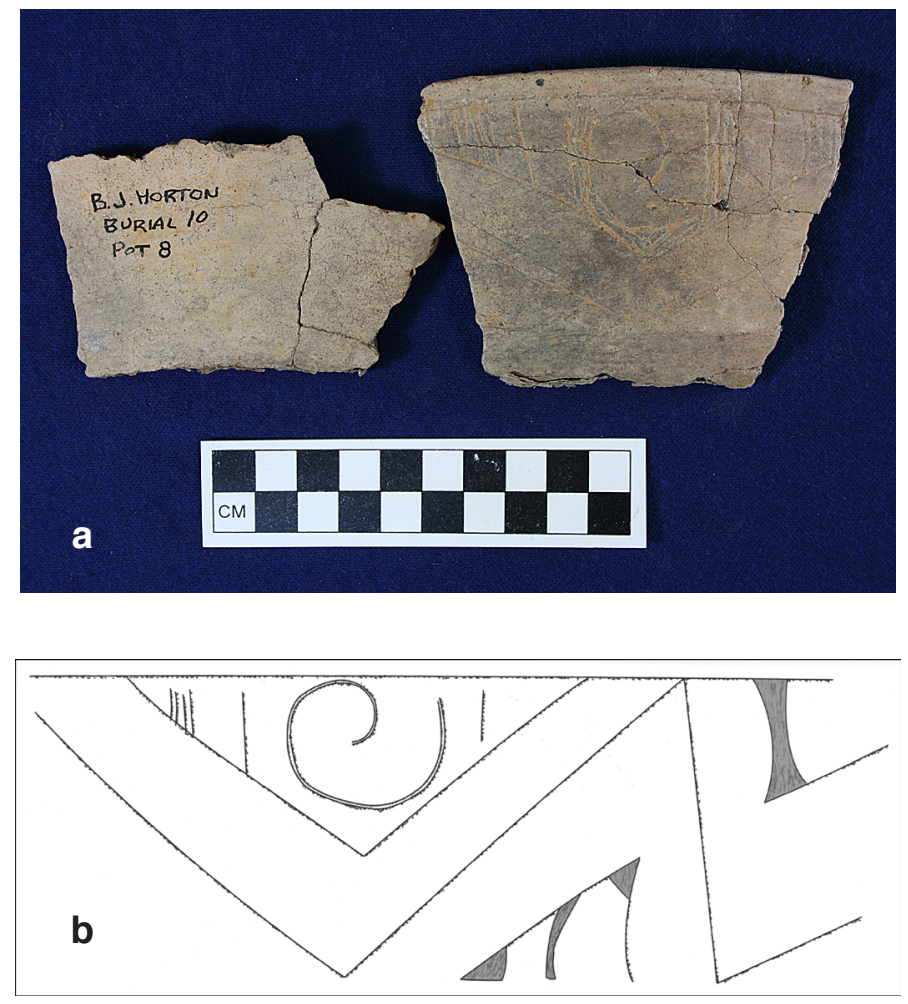

Figure 38. Ripley Engraved, var. Williams-Carpenter carinated bowl from Burial 10 (Pot 8) at the Harold Williams site: a, vessel section; $b$, decorative elements.

BASE DIAMETER (IN CM) AND SHAPE OF BASE: N/A; circular and flat

ESTIMATED VOLUME (IN LITERS): N/A

DECORATION (INCLUDING MOTIF AND ELEMENTS WHEN APPARENT): The rim panel has alternating series of two engraved continuous scroll and two alternating nested triangle motifs (Figure 38ab). The upper and lower scroll fill zones associated with the continuous scroll motifs have excised brackets, columns, and triangles forming negative ovals, columns, and triangles. The nested triangle motifs have a central hooked arm element and sets of closely-spaced vertical engraved lines.

PIGMENT USE AND LOCATION ON VESSEL: none

TYPE AND VARIETY (IF KNOWN): Ripley Engraved, var. Williams-Carpenter 
SITE NAME OR SITE NUMBER: B. J. Horton

VESSEL NO.: Burial 10, Pot 12

VESSEL FORM: Compound bowl

NON-PLASTICS AND PASTE: bone

RIM AND LIP FORM: Direct rim and rounded lip

CORE COLOR: $\mathrm{G}$ (fired in a reducing environment and cooled in the open air)

INTERIOR SURFACE COLOR: yellowish-brown; fire clouds on the body and base

EXTERIOR SURFACE COLOR: very dark grayish-brown

WALL THICKNESS (IN MM): rim, $4.1 \mathrm{~mm}$; body, $4.2 \mathrm{~mm}$; base, $5.2 \mathrm{~mm}$

INTERIOR SURFACE TREATMENT: smoothed

EXTERIOR SURFACE TREATMENT: smoothed

HEIGHT (IN CM): N/A; rim panels, $4.8 \mathrm{~cm}$

ORIFICE DIAMETER (IN CM): 12.0

DIAMETER AT BOTTOM OF RIM OR NECK (IN CM): 12.0

BASE DIAMETER (IN CM) AND SHAPE OF BASE: 5.9; circular and flat

ESTIMATED VOLUME (IN LITERS): N/A

DECORATION (INCLUDING MOTIF AND ELEMENTS WHEN APPARENT): The upper rim panel has a single centrally-placed horizontal engraved line. The lower rim panel has sets of two cross-hatched bracket elements divided by two vertical engraved lines. These elements create open oval-shaped and rectangular-shaped zones on the rim (Figure 39).

PIGMENT USE AND LOCATION ON VESSEL: none

TYPE AND VARIETY (IF KNOWN): Unidentified fine ware

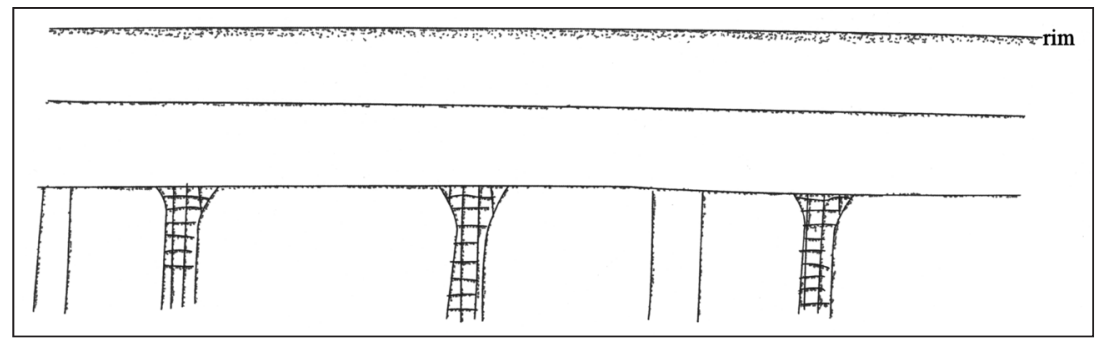

Figure 39. Decorative elements on unidentified engraved compound bowl from Burial 10 (Pot 12) at the Harold Williams site. 
SITE NAME OR SITE NUMBER: B. J. Horton

VESSEL NO.: Burial 15, Pot 7

VESSEL FORM: Jar

NON-PLASTICS AND PASTE: grog

RIM AND LIP FORM: N/A

CORE COLOR: $\mathrm{F}$ (fired in a reducing environment and cooled in the open air)

INTERIOR SURFACE COLOR: brown; fire clouds on the body

EXTERIOR SURFACE COLOR: brown; fire clouds on the body

WALL THICKNESS (IN MM): body, $6.5 \mathrm{~mm}$; base, $12.2 \mathrm{~mm}$

INTERIOR SURFACE TREATMENT: smoothed

EXTERIOR SURFACE TREATMENT: smoothed

HEIGHT (IN CM): N/A

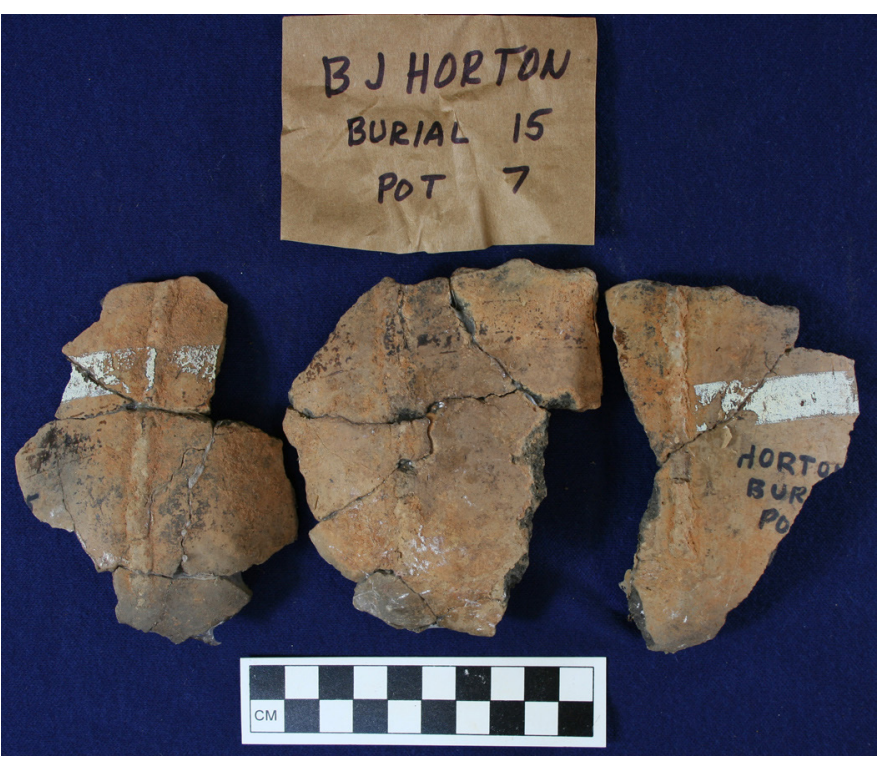

Figure 40. McKinney Plain jar from Burial 15 (Pot 7)

ORIFICE DIAMETER (IN CM): N/A at the B. J. Horton site.

DIAMETER AT BOTTOM OF RIM OR NECK (IN CM): N/A

BASE DIAMETER (IN CM) AND SHAPE OF BASE: 7.5; circular and flat

ESTIMATED VOLUME (IN LITERS): N/A

DECORATION (INCLUDING MOTIF AND ELEMENTS WHEN APPARENT): The vessel body has an undetermined number of vertical appliqued ridges (Figure 40).

PIGMENT USE AND LOCATION ON VESSEL: none

TYPE AND VARIETY (IF KNOWN): McKinney Plain 


\section{Alex Justiss Site (41TT13)}

The Alex Justiss site (41TT13) is principally a 17th century Titus phase cemetery on an upland ridge landform in the Swauano Creek valley in the Big Cypress Creek basin (Bell 1981; Rogers et al. 2003) (see Perttula et al. 2010:Figure 6). During excavations by Ralph Nicholas, Ed German, and Bob Turner in 1959, a total of 27 Caddo burials were excavated in the cemetery, with at least 182 ceramic vessels placed in the graves as funerary offerings, along with 69 arrow points (including 10 unique side-notched points, see Bell 1981:Figure 41) and a ceramic pipe (Bell 1981:Tables 4 and 5). An additional burial (Burial 28) was excavated by PBS\&J some years later, and prior to the expansion of SH 49 across the site (Rogers et al. 2003:Figure 10). 
SITE NAME OR SITE NUMBER: Alex Justiss

VESSEL NO.: Burial 24, Pot 1

VESSEL FORM: Carinated bowl

NON-PLASTICS AND PASTE: grog

RIM AND LIP FORM: Direct rim and rounded, exterior folded lip

CORE COLOR: $\mathrm{F}$ (fired in a reducing environment and cooled in the open air)

INTERIOR SURFACE COLOR: dark yellowish-brown; fire clouds on the rim, body, and base

EXTERIOR SURFACE COLOR: yellowish-brown; fire clouds on the rim, body, and base

WALL THICKNESS (IN MM): $\operatorname{rim}, 5.3 \mathrm{~mm}$

INTERIOR SURFACE TREATMENT: smoothed

EXTERIOR SURFACE TREATMENT: smoothed

HEIGHT (IN CM): 6.5

ORIFICE DIAMETER (IN CM): 15.5

DIAMETER AT BOTTOM OF RIM OR NECK (IN CM): 13.6

BASE DIAMETER (IN CM) AND SHAPE OF BASE: 8.0; circular and flat

ESTIMATED VOLUME (IN LITERS): 0.6

DECORATION (INCLUDING MOTIF AND ELEMENTS WHEN APPARENT): The rim panel has an engraved horizontal scroll motif repeated four times around the vessel. The scrolls are divided by open brackets with an excised pendant triangle on each side of the bracket. The horizontal scrolls have either an upper or lower curvilinear scroll fill zone with two vertical engraved lines within each zone (Figure 41).

PIGMENT USE AND LOCATION ON VESSEL: none

TYPE AND VARIETY (IF KNOWN): cf. Ripley Engraved, var. Gandy

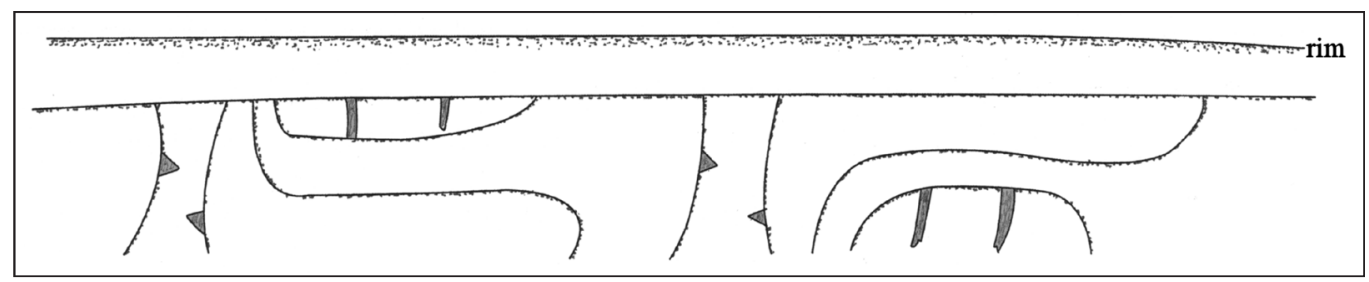

Figure 41. cf. Ripley Engraved, var. Gandy carinated bowl from Burial 24 (Pot 1) at the Alex Justiss site. 


\section{Summary and Conclusions}

The 38 ancestral Caddo ceramic vessels documented in this report from the Robert L. Turner, Jr. collection in the Anthropology and Archaeology Laboratory at Stephen F. Austin State University are from five sites in the Big Cypress Creek basin in East Texas: G. W. Rumsey (41CP3), Tuck Carpenter (41CP5), Harold Williams (41CP10), B. J. Horton (41CP20), and Alex Justiss (41TT13). Perttula et al. (2010) previously documented a number of other vessels from these same sites. These vessels are funerary objects that had been placed with Caddo burials in cemeteries at each of the sites.

The decorative elements and motifs on these vessels, as well as the various vessel forms represented in the collections, are consistent with Late Caddo period, Titus phase (ca. A.D. 1430-1680) vessel assemblages in the Big Cypress Creek basin. The vast majority of these vessels are tempered with grog, and were fired in a low oxygen or reducing environment, but then cooled in the open air.

The fine wares in the collection are dominated by several varieties of Ripley Engraved (var. Cash, var. Galt, var. Gandy, var. Carpenter, var. McKinney, cf. var. Gandy, and var. Williams, as well as var. unspecified), the principal Titus phase fine ware; these include carinated bowls and compound bowls (including one with rim peaks). Another fine ware in the collection is Turner Engraved, var. Turner. This type/decorative style occurs on compound bowls.

Utility wares in this part of the Turner collection include Maydelle Incised, La Rue Neck Banded, McKinney Plain, and Mockingbird Punctated jars, as well as jars with vertical incised decorative elements; and several jars with punctated-appliqued-brushed elements on the vessel rim and/or body, including one vessel with rim peaks. One small bowl has horizontal incised lines on the rim as well as a plain tab tail.

Although they are not common, there are also plain wares in this part of the Turner collection. They include carinated bowls, bottles, and jars. 


\section{References Cited}

Bell, M.

1981 The Alex Justiss Site: A Caddoan Cemetery in Titus County, Texas. Publications in Archaeology, Highway Design Division Report No. 21. Texas State Department of Highways and Public Transportation, Austin.

Brown, J. A.

1996 The Spiro Ceremonial Center: The Archaeology of Arkansas Valley Caddoan Culture in Eastern Oklahoma. 2 Vols. Memoirs No. 29. Museum of Anthropology, University of Michigan, Ann Arbor.

Ferring. C. R. and T. K. Perttula

1987 Defining the Provenance of Red-Slipped Pottery from Texas and Oklahoma by Petrographic Methods. Journal of Archaeological Science 14:437-456.

Gadus, E. F., R. C. Fields, J. K. McWilliams, J. Dockall, and M. C. Wilder

2006 National Register Testing of Seven Prehistoric Sites in the Sabine Mine's Area Q, Harrison County, Texas. Reports of Investigations No. 147. Prewitt \& Associates, Inc., Austin.

Hunt, S. M., F. B. Largent, Jr., and M. B. Cliff

1996 Cultural Resources Evaluation of the Pilgrim's Pride Property South of Big Cypress Creek, Camp County, Texas. Miscellaneous Report of Investigations No. 118. Geo-Marine, Inc., Plano.

Perttula, T. K.

2014 The Horton Site (4CP20). In Archeological Investigations at the Kitchen Branch (41CP220), B. J. Horton (41CP20), and Keering (41CP21) Sites, Big Cypress Creek Basin, Camp County, Texas, by T. K. Perttula and M. D. Miller, pp. 451-456. AmaTerra Environmental, Inc., Austin.

Perttula, T. K. (editor)

2005 Archeological Investigations at the Pilgrim's Pride Site (41CP304), a Titus Phase Community in the Big Cypress Creek Basin. 2 Vols. Report of Investigations No. 30. Archeological \& Environmental Consultants, LLC, Austin.

Perttula, T. K. and B. Nelson

2004 Archeological Investigations at the Shelby Site (41CP71) on Greasy Creek, Camp County, Texas. Special Publication No. 5. Friends of Northeast Texas Archaeology, Pittsburg and Austin.

Perttula, T. K. and R. Z. Selden, Jr.

2014 Ancestral Caddo Ceramics in East Texas. Journal of Northeast Texas Archaeology 48, in press.

Perttula, T. K., M. Walters, and B. Nelson

2010 Caddo Pottery Vessels and Pipes from Sites in the Big Cypress, Sulphur, Neches-Angelina, and Middle Sabine River Basins in the Turner and Johns Collections, Camp, Cass, Cherokee, Harrison, Morris, Titus, and Upshur Counties, Texas and Sabine Parish, Louisiana. Special Publication No. 10. Friends of Northeast Texas Archaeology, Pittsburg and Austin.

Rice, P. M.

1987 Pottery Analysis: A Sourcebook. University of Chicago Press, Chicago. 
Rogers, R., M. B. Cliff, T. K. Perttula, G. Rutenberg, S. Victor, P. Dering, and M. Malainey

2003 Excavations at the Alex Justiss Site, 41TT13, Titus County, Texas. Archeological Studies Program Report No. 36. Texas Department of Transportation, Austin.

Skibo, J. M.

1992 Pottery Function: A Use-Alteration Perspective. Plenum Press, New York.

Suhm, D. A. and E. B. Jelks (editors)

1962 Handbook of Texas Archeology: Type Descriptions. Texas Archeological Society Special Publication 1 and Texas Memorial Museum Bulletin 4, The University of Texas at Austin.

Teltser, P. A.

1993 An Analytic Strategy for Studying Assemblage-Scale Ceramic Variation: A Case Study from Southeast Missouri. American Antiquity 58(3):530-543.

Thurmond, J. P.

1990 Archeology of the Cypress Creek Drainage Basin, Northeastern Texas and Northwestern Louisiana. Studies in Archeology 5. Texas Archeological Research Laboratory, The University of Texas at Austin.

Turner, R. L., Jr.

1978 The Tuck Carpenter Site and Its Relation to Other Sites Within the Titus Focus. Bulletin of the Texas Archeological Society 49:1-110.

1992 Prehistoric Mortuary Remains at the Tuck Carpenter Site, Camp County, Texas. Studies in Archeology No. 10. Texas Archeological Research Laboratory, The University of Texas at Austin.

1997 Observations on Four Probable Middle Caddo Cemeteries in Camp and Upshur Counties. Journal of Northeast Texas Archaeology 10:12-35.

Turner, R. L., Jr. and J. E. Smith II, with contributions by T. K. Perttula, B. Nelson, M. Walters, and B. Gonzalez

2003 The Harold Williams Site (41CP10) and the Texas Archeological Society Field School of 1967. Bulletin of the Texas Archeological Society 73:1-68. 